\title{
A Correlational Study of Organizational Key Behavior and Teachers' Competencies in Sapangdalaga District Division of Misamis Occidental Sy 2020-2021
}

\author{
Pearly Mae B D'lonsod
}

Medina College, Philippines

\begin{abstract}
School Organizations are consciously and highly organized system that comprises teachers with varied interests, needs, orientation and preparation. Through these various interests among the school members, organizations have to pave the way for effective behavior to achieve their desired goals and objectives. This study attempted to ascertain the relationship between organizational behaviors and teachers' competence. Indicators in teachers organizational key behavior are Communication, Judgement and Decision Making, Leadership, Teamwork were all perceived high, while there is only one indicator - Creativity - with meaning "identifying and visualizing options and formulating innovative approaches" was perceived as very high $(\mathrm{M}=4.25, \mathrm{SD}=0.97)$. The Teachers' level of instructional competence constituted a verbal interpretation of "Good" for all its components and indicators. Furthermore, only four indicators showed significant relationships which were Instructional Process and Communication $\mathrm{X}^{2}(1, \mathrm{~N}=143)=37.27, \mathrm{p}<0.05 \mathrm{~V}_{\text {Cramer }}=$ 0.51 , Professionalism and Communication $\mathrm{X}^{2}(1, \mathrm{~N}=143)=5.324, \mathrm{p}<0.05 \mathrm{~V}_{\text {Cramer }}=0.19$, Planning and Leadership $\mathrm{X}^{2}(1, \mathrm{~N}=143)=121.677, \mathrm{p}<0.05 \mathrm{~V}_{\text {Cramer }}=0.922$ and Assessment and Teamwork $\mathrm{X}^{2}(1, \mathrm{~N}=143)=6.762, \mathrm{p}<0.05 \mathrm{~V}_{\text {Cramer }}=0.217$. Among these associations, it can be noted that a "near-perfect association" was drawn between planning and leadership which entails a very strong effect of each variable on one another. Thus, effective leaders were always equipped with strategic vision, mission, and goals.
\end{abstract}

\section{Chapter 1 - Introduction}

\section{Background of the Study}

The success and failure of any school organization are directly reciprocal to its leadership efficiency and effectiveness. Effective school planning, organizing, staffing, directing, and coordinating employ by school administrators lead to a successful organization and job satisfaction among teachers. The importance of working with, understanding, and motivating teachers both individually and in groups defines school administrators' social skills. School administrators' social skills are significant to others' interaction with others, and the quality of this interaction determines the organizational spirit and teachers' commitment and dedication. For the quality of the teacher's 'job and supportive work environment, school administrators' human skill is of great significance in any educational institution.

School Organizations are consciously and the highly organized system that comprises teachers with varied interests, needs, orientation, and preparation. Through these various interests among the school members, organizations paved the way for effective behavior in an organization to achieve 
its desired goals and objectives. The study of school organizational behavior leads to teachers' effectiveness and enhancement of job performance. The essential areas that need to look into consideration are, nature and features of school organizational behavior and coverage of organizational behavior.

Organizational behavior in school describes the behaviors and attitudes of teachers and the school organization as a whole. School's action does not just lie in the specific norms for individual and group behavior and the degree to which teachers follow those norms. It also matters what actual behavior patterns achieve for the teaching-learning process regarding teachers' performance and commitment to the organization.

Human Behavior in Organization (HBO) is studying human behavior in organizational settings, the relationship and interaction between individual behavior and the organization where he belongs. Researchers check individual behavior primarily focuses on its roles in a given organization. One of the primary purposes of studying human behavior in an organization is to emphasize the importance of organizational theory and develop a better corporate life concept.

As a multidisciplinary field, Human Behavior in Organization is strengthening its relationship with other allied disciplines' developments, including sociology, education, psychology, economics, engineering, and practitioners' experience. The school organizations in which teachers work significantly impact their thoughts, feelings, and actions as members of the country's most prominent bureaucratic organization, the Department of Education (DepEd). The ideas, feelings, and acts of teachers, in turn, affect the school organization itself. Human Behavior in Organization looks into the process governing the interactions between teachers and school organizations. They seek to identify and foster behaviors that are conducive to the strength and effectiveness of school organization.

Recognizing the importance of school organizational behavior leads to the establishment of organizational structure. These structures are necessary for a school organization. It allows the school organization members to work out on a unified effort to achieve corporate aims. School administrators guide teachers in every organization by providing continuous guidance in day-to-day activities in school. Teacher's behavior dictates the strongest will be highest in a hierarchy, as it is for those in organization teachers have tremendous respect. For instance, it will be those with the most work experience and the highest standard of qualifications who gain high school hierarchy positions.

\section{Review of Related Literature and Studies}

Organizational culture and climate describe by theorists (Miner 1995). Hoy et al. (1991) distinguish between environment and culture, with school or organizational climate viewed from a psychological perspective and school culture as viewed from an anthropological perspective. The differences between school climate and culture are highlighted in organizational studies. The climate is often viewed as behavior, while culture comprises the school or organization's values and norms (Hoy 1990, Heck and Marcoulides 1996). Lunenburg and Ornstein (2004) described the organizational climate as the total environmental quality within an organization and believe that the recent attention to public schools' effectiveness and their cultures have shed more interest on 
climate importance. Schein $(1985,1996)$ supported the relationship between culture and climate, stating that norms, values, rituals, and climate are all manifestations of culture. McDougall and Beattie (1998) supported the relationship between culture and climate and the early studies of Schneider and Reichers (1983).

Batlolona (2018) explained that a positive work climate in school would also result in a pleasant working environment and subsequently impact students' behavior, especially the teachers. School climate and work culture play vital roles in improving teacher's performance. A positive work climate and culture motivates and inspires teachers to be creative and innovative, leading to a growing positive direction.

Kapur (2018), in his study on organizational behavior in education, revealed that effective implementation of organizational behavior in education contributes to the enhancement of job performance, incurs job satisfaction, and leads to the achievement of desired goals and objectives. The study includes the nature and features of organizational behavior, the scope of organizational behavior, and the need for organizational behavior in education, the educational field's contribution to organizational behavior, career development, challenges, and opportunities for organizational behavior.

In an article, Kunter, Baumert, Voss, Klusmann, Richter, Hatchfeld (2013) conducted a study to investigate teachers' pedagogical content knowledge, professional practices, work-related motivation, and self-regulation aspect concerning teachers' professional competence. Specifically, it sought to examine how these aspects correlate to instruction and students' learning. In a representative sample of 194 German secondary school mathematics classes, multiple measures employ to assess teacher competence, instructional quality, and students' achievement and motivation. The influence of teachers' professional attributes towards student learning revealed positive results based on the repeated-measures design. The structural equation models show positive effects of teachers' pedagogical content knowledge and enthusiasm towards teaching instructional quality, affecting student outcomes. In contrast, the general academic ability of teachers did not significantly affect their instruction. The multidimensional professional competence model introduced in this article seems to stimulate further research on teacher quality indicators.

A case study of Yusof (2012) analyzes the relationships between school climate and teachers' commitment. The study investigates the predictability of school climate's fundamental dimensions related to collegial leadership, professional teacher behavior, achievement press, and institutional vulnerability towards teacher commitment. The study found that school climate openness and teachers' commitment to the selected five primary schools are high. As for the correlation between school climate dimensions, the result shows a positive relationship with teachers' responsibility. The regression analysis of professional teacher behavior made a significant contribution to teachers' commitment.

\section{Related Studies}

Rashid et al. (2018) stressed that teachers' behavior significantly correlates with student academic performance. Out of these eight components, the results revealed that six features (clarity, 
interaction, pacing, disclosure, speech, and rapport) show a highly significant relationship with students' academic performance. In comparison, two components (enthusiasm and organization) have no association with the dependent variable. Students have substantial differences in their academic performance, while only one component (speech) reveal differences based on their (student's) gender. Introduction Teachers' behaviors the term used for the behavioral manifestation of the act of teaching, done to facilitate the learning by a student or a group of students. Therefore, it encompasses all the verbal and nonverbal behaviors demonstrated by a teacher to impart education within an academic setting. The teaching approach and techniques employed by teachers have different results for student performances. Therefore, teachers play a vital role in providing an encouraging learning environment for their students to excel academically. Therefore, a significant portion of the onus for quality learning falls upon the teacher's personality and attitude. Education occurs through the marriage of teaching and learning; therefore, knowledge is halfway essential and has an equal, if not more significant, share in students' academic performance. The learning tendency and behavior differ from student to student. However, since this study's focus is on the need side of the education equation, we do not detail students' learning behavior and leave that topic for a different project at this stage.

Blazar (2016) pointed out that teachers have large effects on students' attitudes and behaviors and their relationship to students' performance. Teacher's impact estimates to have a moderate to strong predictive validity. The prediction of student outcomes by teaching practices is the most proximal measure in the relationship between teachers' math errors and students' math achievement. Teachers' results showed that teachers who are effective at improving some outcomes are not equally effective in enhancing others. This study's findings provide empirical evidence that established a theory in the teaching-learning process's creating policies that account for and incentivize this complexity.

This study attempts to identify teacher and teaching effects using observations of instruction inside teachers' classrooms. This study uses random assignment to determine the teacher's predictive validity on students' attitudes and behaviors. Results from this study will result to inform policy and practice in two significant contributions.

First, exploring the impact of specific teaching methods on student outcomes may help policymakers and school leaders get more teachers who engage in these effective teaching practices into classrooms. This practice occurs through evaluation or development practices. When school leaders observe classrooms, they look into those elements of instruction that contribute to student outcomes. Moreover, school leaders may use this information to link teachers to professional development opportunities to improve their particular instructional domain skills.

Secondly, the results show strong teacher effects on student attitudes and behaviors and weak relationship on teacher effects on students' outcomes, highlighting the multidimensional nature of teaching. Moreover, as stated above, these teaching practices may be a focus of development efforts.

Filling up classrooms with teachers who positively engage in effective teaching practices will take more time. More so likely will entail various efforts, including improvements in professional 
development offerings that engage teachers substantively around their teaching practices and more concrete actions to hire teachers with in-depth knowledge of teaching Mathematics. Most Importantly, though, the education community is beginning to understand the teaching types that students needed to raise outcomes.

Sabado (2014), in her study which sought to describe the socio-demographic characteristics of the thirty-four (34) public school heads and one hundred thirty (130)teachers, eight school heads, and 40 teachers from private high schools in Kidapawan City Division. The study includes the school climate that influences school heads' leadership behavior in public and private high school teachers' performance.

The researcher's recommendations are the following measures:

1. Training seminars workshops such as team building activities, curriculum planning, and school events need to strengthen to intensify the camaraderie and healthy relationship among teachers.

2. The school heads should possess good leadership behavior since they are the leaders of their schools who are looked up to by the teachers, pupils, and stakeholders. Their good leadership is one factor that will create a positive school climate, which can contribute to a teacher's job satisfaction, thereby motivating them to work better.

3. The school heads must maximize their efforts in creating a positive school climate in their school to produce teacher's teachers' quality performance.

4. Teachers must also be encouraged to pursue higher education by enrolling in graduate programs to enhance their competence in instruction and personal characteristics to maintain a good school climate and understand their school heads' leadership behavior.

5. A further study of this topic includes other factors that may influence teachers' performance and compare the school climate and public and private institutions' leadership behavior.

The school climate significantly influenced the school heads' leadership behavior. The instructional management domain of school climate significantly influenced leadership behavior in terms of human relations. The teacher-student relation domain in school climate significantly influences trust and decision making in leadership behavior; the school climate domains like security maintenance, student-peer relationship, and instructional management significantly influenced the leadership behavior in terms of control. Teacher-student relations and student academic orientation in school climate significantly influenced the leadership behavior in times of conflict.

The socio-demographic characteristics, school climate, and leadership behavior did not significantly influence the teachers' job performance.

Villaluz (2018) assesses public schools' organizational climate in the Sibulan District using Ekvall's nine climate dimensions, including school heads and teachers' demographic profiles and the variables' relationship. This study's Respondents were 31 school heads and 257 teachers in the public elementary and secondary schools of the Sibulan District. Villaluz study's point of contact and the present work is that both works appraised the organizational climate and behavior. The former dissertation studied school administrators and teachers' organizational climate and the relationship among the variables. In contrast, the present study will determine the organizational 
behavior of elementary school teachers of Sapangdalaga District concerning teachers' competence in teaching.

Kadtong et al. (2013), in their study, sought to determine the relationship between the teacher's work performance and job satisfaction in the Division of Cotabato City. The study results revealed that most teachers are within the 31-40 years old age bracket. The majority of the teachers are females, married, earned a baccalaureate degree in education with a master's degree unit. Sixty- four percent of the respondents had 11 to 15 years in the service. Findings concluded that the teacher respondents of the Division of Cotabato City show a high teaching performance level. They are satisfied and contented in their job resulting in teacher's job satisfaction concerning policies, administration, supervision, salary, working conditions, work itself, and personal and professional development. The study concluded that teachers would become productive and committed to their job if teachers are satisfied with their job. Furthermore, if teachers' contentment with their job, it will maintain teachers' high moral level, resulting in teachers' effective and efficient performance. Effective teaching-learning processes produce quality learners.

Teven (2007), in his study which sought to investigate the impact of teacher's misbehaviors and the way the care on students correlates teacher's evaluation and teacher's teaching competence and trustworthiness. After thorough research on teachers' hypothetical situations engaged in very appropriate (or inappropriate) behaviors and communicating caring (or non-caring), students reported perceptions of teacher competence and trustworthiness, and affect. The analysis of variance shows significant main effects for teacher caring and appropriateness on competence and reliability. Even though there were correlations on interaction, the conflict was on correlations. Teacher caring was significantly related to students' effect on the subjects and the teacher. This study revealed that teachers should maintain appropriate classroom behavior and shows care towards students to preserve their credibility and affect the classroom.

\section{Theoretical Framework of the Study}

Over the past decade, various researches have confirmed that teachers substantially impact their students' academic and life-long success. Despite the concerted efforts to identify characteristics such as experience and education that might correlate with teacher effectiveness, the nature of effective teaching still largely remains a dilemma.

A teacher's performance is the total of the teacher's ability, motivation, and environment. To explore what roles that motivation plays in a teacher's performance, it is essential to consider the source of inspiration in the workplace and how to use these working theories to help teachers become more engaged in their respective work.

An organizational structure plays a crucial role in the success of an educational institution. Thus, the organizational theories help identify the suitable design for an organization, efficient enough to deal with specific problems.

The modern theory integrates essential ideas of the classical models of organizational behavior and social and behavioral sciences. This theory looks organization as a system that changes with its environment, covering both internal and external. The modern approach considered an organization 
to interact with its environment to sustain and grow consistently. With the adoption of an organization as an open system, several elements exist, such as input, transformation, process, output, feedback, and environment. This theory contradicts the classical approach, where the organization is being considered a closed system.

Since the organization is an open system, where the environment changes primarily to determine survival and growth, it is also said to be adaptive and adjusts itself to the changing climate.

This theory comprises of the different levels and dimensions of the organization. This theory covers both the micro and macro environment of the organization. The macro size and level cover the external environment, while the micro-environment is internal to the organization.

This study focused on Teachers' effectiveness concerning teachers' essential organizational behavior in Sapangdalaga District, Division of Misamis Occidental.

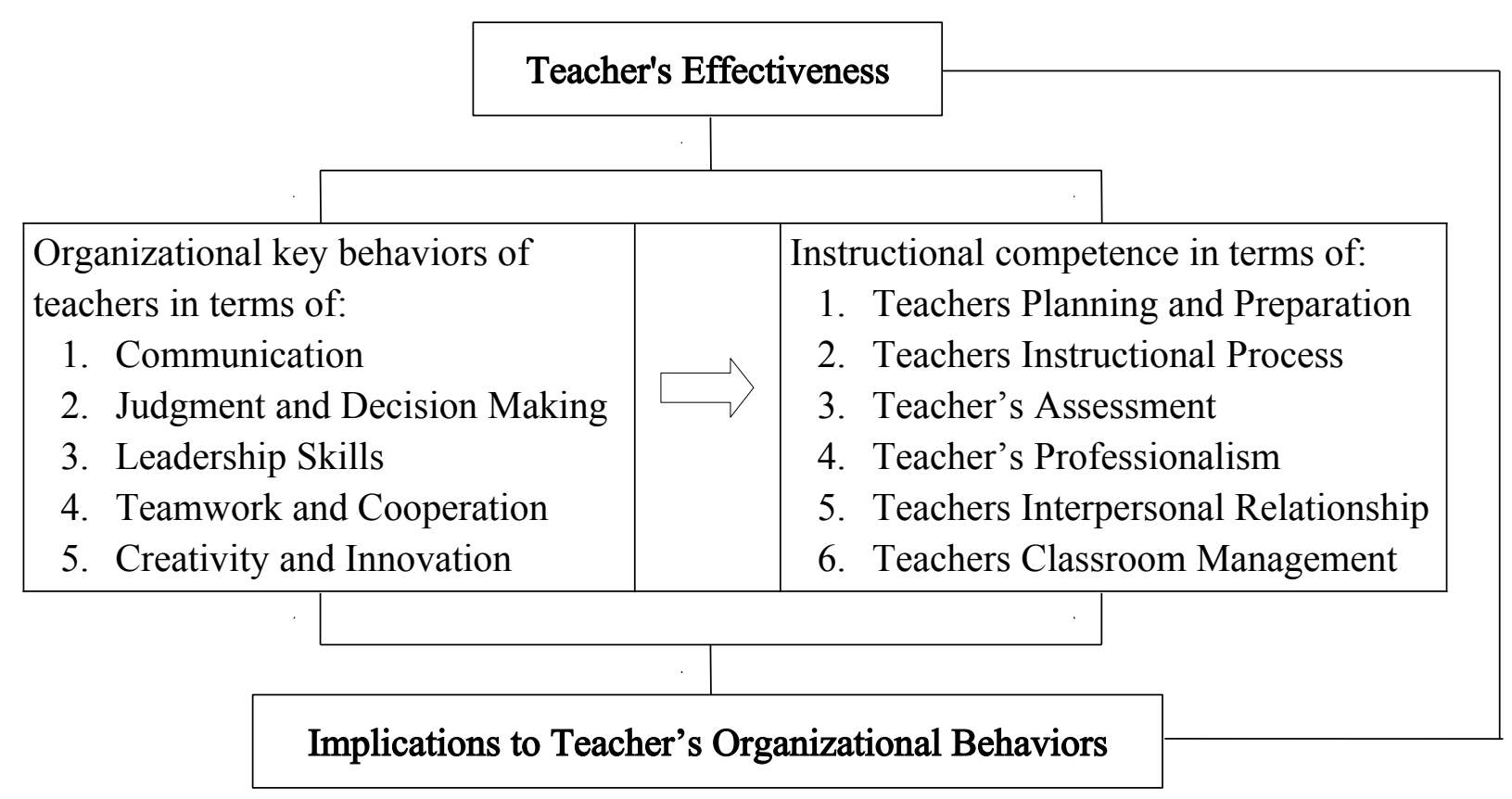

Figure 1 - Schematic Presentation of the Study

This figure illustrates how organizational behaviors in terms of communication, judgment and decision-making, leadership skills, teamwork and cooperation, and creativity and innovation affect teachers' competence in planning and preparation, instructional processes, assessment practices, classroom management, professionalism, and interpersonal relations.

\section{Statement of the Problem}

This study attempted to ascertain the relationship of organizational behaviors and teachers' competence of the Sapangdalaga District, Division of Misamis Occidental, for the School Year 2020-2021.

Specifically, this study answered the following questions:

1. What are the levels of the organizational behaviors of teachers in terms of: 

1.1 Communication;
1.2 Judgment and Decision Making;
1.3 Leadership Skills;
1.4 Teamwork and Cooperation;
1.5 Creativity and Innovation?

2. What is the level of the instructional competence of teachers in terms of:
2.1 Planning and Preparation;
2.2 Instructional Process;
2.3 Assessment;
2.4 Professionalism;
2.5 Interpersonal Relationship;
2.6 Classroom Management?

3. Is there a significant association between organizational behavior and instructional competence towards a teacher's effectiveness?

\section{Hypotheses}

Ho: There is no significant relationship between the teachers organizational behaviors and instructional competence towards the teacher's effectiveness.

\section{Significance of the Study}

This study aimed to ascertain the relationship between teachers' organizational behavior and competence towards effectiveness in Sapangdalaga District, Division of Misamis Occidental teacher's point.

This study's results may be beneficial to all teachers involved in the teaching-learning process, particularly in this area.

In specific terms, the result derived from this investigation will help the school administrators gain a more in-depth insight into the teachers' effectiveness and devise proper measures for improvement.

The results of this study may also guide the teacher to improve their skills and competencies and help them realize their essential role in the educative process. Findings may provide a basis for enhancing, enriching, or adopting other techniques to improve their instruction.

To the students, who are the most important beneficiaries of this investigation, it is necessary that at this stage, they already developed proper and favorable attitudes of the teachers that lead to effective and efficient learning.

The study results were beneficial to the researchers as a link in utilizing research findings for planning and practical solutions to instruction effectiveness problems. Such findings may serve as a good source of information regarding teachers' competence and effectiveness in instruction related to teachers' organizational behavior. Teachers, school administrators, and supervisors will hopefully utilize this study's findings in varied ways depending upon their needs, purposes, and functions in the system. 
Finally, this study's results may add to the existing data on the different organizational behavior factors that affect the teaching-learning process.

\section{Scope and Limitation of the Study}

This study focused on investigating the relationship of organizational behavior and instructional competence towards teacher's effectiveness of Sapangdalaga, Misamis Occidental using five organizational behavior variables, namely: Communication: Judgment and Decision Making, Leadership Skills, Teamwork and Cooperation, and Creativity and Innovation and six instructional competence, namely: Planning and Preparation; Instructional Process, Assessment, Professionalism, Interpersonal Relationship, and Classroom Management. Schools involved were the twenty elementary schools. One half of the total population of five hundred elementary school teachers serve as respondents. The duration of this study is within S.Y. 2020-2021.

\section{Definition of Terms and Clarification of Concepts}

As in any study, terms are usually furnishing a common ground for understanding between the reader and the researcher.

Assessment: It is the collection of relevant information that may be relied on for making decisions.

Classroom Management: Pertains to teachers' skills, techniques, and strategies to keep students orderly, organized, attentive on the assigned task, and meaningfully learned during a class. When teachers effectively execute classroom-management strategies, he minimizes the students' behaviors that affect students' learning, maximizing students' actions to facilitate and enhance learning. Generally speaking, effective teachers tend to display strong classroom-management skills. In contrast, the inexperienced or less effective teacher's hallmark is a disorderly classroom filled with students who are not working or paying attention.

Creativity: These how teachers used her knowledge, curiosity, imagination, and evaluation. The more excellent understanding of the teacher and level of interest he has, the more ideas, patterns, and combinations he can achieve, which then correlates to creating new and innovative products and services.

Evaluation: This study refers to applying a set of standards and a decision-making criterion to make sound judgments that pertain to the learning's adequacy.

Judgment and Decision Making Ability: Refers to capacity or faculty to make considered and effective decisions, come to sensible conclusions, perceive and distinguish relationships, understand situations, and form objective opinions, especially in matters that affect action.

Leadership Skills: This study refers to the strengths and abilities individuals demonstrate that help them oversee processes, guide initiatives, and steer their employees toward achieving goals.

Organizational Behavior (O.B.): Organizational behavior refers to studying human behavior in organizational settings, the interface between human behavior and the organization, and its own. 
Organizational Communication: In this study, it is how members of an organization interact with each other and the people they serve.

Planning and Preparation: It refers to one of the essential principles of good teaching is the need for planning. Planning provides teachers and students a structure for reflection and evaluation.

Professionalism: Refers to the conduct, aims, or qualities that characterize or mark a professional or a professional person

Teacher: In this study, it is a person who helps students to acquire knowledge, competence, or virtue.

Teachers Competence: According to Mc. Leod (in Usman, 2004:14) "the ability of a teacher to responsibly perform her duties or has appropriately." Teachers' competence is the teacher's ability to implement the obligations in a responsible and viable.

Teamwork and Cooperation: This study is part of a group and collaborates with other members toward achieving a common work-related goal.

\section{Chapter 2 - Methods}

This chapter presents the research design, participants and sampling technique, research instruments, data gathering procedure, data analysis, and statistical treatment.

\section{Research Design}

This investigation used the descriptive - survey method in gathering the required information and data on the relationship of organizational behaviors and teacher's competence of elementary school teachers of Sapangdalaga District, Division of Misamis Occidental.

Descriptive research methods provide an accurate portrayal of the characteristics of an individual and a particular situation.

This study is a means of discovering new meaning, describing what exists, determining the frequency with which something occurs, and categorizing information.

\section{Participants and Sampling Technique}

The study respondents were the one hundred forty-three elementary school teachers of Sapangdalaga District, Misamis Occidental, assigned in different grade levels. No sampling technique was being utilized in the study for the population universe served as the subject of investigation.

Table 1 - Distribution of Respondents by School

\begin{tabular}{|l|l|l|l|}
\hline School & Male & Female & Total \\
\hline
\end{tabular}




\begin{tabular}{|l|c|c|c|}
\hline Bautista Elementary School & 1 & 3 & 4 \\
\hline Bitibut Integrated School & 1 & 12 & 13 \\
\hline Boundary Primary School & 0 & 1 & 1 \\
\hline Caluya Elementary School & 0 & 4 & 4 \\
\hline Capundag Elementary School & 1 & 2 & 3 \\
\hline Casul Elementary School & 0 & 5 & 5 \\
\hline Dalumpinas Elementary School & 1 & 2 & 3 \\
\hline Dioyo Elementary School & 1 & 3 & 4 \\
\hline Dasa Elementary School & 0 & 3 & 3 \\
\hline Disoy Elementary School & 1 & 2 & 3 \\
\hline El Paraiso Elementary School & 0 & 3 & 3 \\
\hline Libertad Elementary School & 1 & 2 & 3 \\
\hline Locus Elementary School & 0 & 4 & 4 \\
\hline Manalac Elementary School & 0 & 6 & 6 \\
\hline Manla Elementary School & 3 & 4 & 7 \\
\hline Masubong Primary School & 1 & 1 & 2 \\
\hline Medallo Elementary School & 2 & 4 & 6 \\
\hline Napilan Elementary School & 0 & 2 & 2 \\
\hline Proceso Saldivar Elementary School & 0 & 6 & 6 \\
\hline Salimpono Elementary School & 1 & 2 & 3 \\
\hline Salvador Elementary School & 0 & 7 & 8 \\
\hline Sinaad elementary School & 6 & 28 & 34 \\
\hline SapangAma Integrated School & 0 & 1 & 1 \\
\hline SapangDalaga Central Elementary School & 1 & 1 & 1 \\
\hline Sixto Velez Primary School & 4 & 4 \\
\hline Upper Bautista Primary School & 0 & 143 \\
\hline Ventura Elementary School & 21 & 6 \\
\hline Total & 1 & 2 & 4 \\
\hline
\end{tabular}

\section{Research Instrument}

The questionnaire is the main data-gathering instrument of the study. Before constructing the questionnaire, the researcher sought information from a knowledgeable person in this particular field and visited school libraries to determine whether research in this field is available. Based on the researcher's results, no study was conducted in Misamis Occidental, more so in Sapangdalaga, Misamis Occidental.

The questionnaire consists of two essential parts. Part I deals with teachers' critical behavior, which contains questions to gather information about communication, judgment and decision-making, leadership skills, teamwork and cooperation, and creativity and innovation. Part II looks into the 
instructional competence of teachers. Namely, the planning and preparation, teacher's instructional process, teacher's assessment, teacher's professionalism, teacher's interpersonal relationship, and teacher's classroom management.

To determine the level of organizational behaviors of teachers, the five-point scale is used:

$$
\begin{aligned}
& 5=\text { Very High } \\
& 4=\text { High } \\
& 3=\text { Average } \\
& 2=\text { Low } \\
& 1=\text { Very Low }
\end{aligned}
$$

Hypothetical Mean Range:

$$
\begin{aligned}
& 4.21-5.00=\text { Very High } \\
& 3.41-4.20=\text { High }
\end{aligned}
$$$$
\text { 2.61-3.40 = Average }
$$$$
1.81-2.60=\text { Low }
$$$$
1.00-1.80=\text { Very Low }
$$

Part two contained statements that describe classroom behaviors, namely:

1. Teachers planning and preparation

2. Teacher's instructional process

3. Teacher's assessment

4. Teacher's professionalism

5. Teacher's interpersonal relationship

6. Teacher's classroom management

The following are the five-point scale:

$$
\begin{aligned}
& 5=\text { Very Good } \\
& 4=\text { Good } \\
& 3=\text { Average } \\
& 2=\text { Below Average } \\
& 1=\text { Unsatisfactory }
\end{aligned}
$$

Hypothetical Mean Range

4.21-5.00 = Very Good

$3.41-4.20=$ Good

2.61-3.40 $=$ Average

1.81-2.60 = Below Average

$1.00-1.80=$ Unsatisfactory

The researcher interviewed the teachers to cross-check the information found in the questionnaire. The interview focused on the relationship of organizational behaviors and teacher's competence of elementary school teachers of Sapangdalaga District, Division of Misamis Occidental. The questions in the questionnaire used as interview guides. 


\section{Instruments Validation}

The research questionnaire undergoes an internal consistency validation through the Cronbach Coefficient Alpha. After the researchers decided what to include in the questionnaire based on the statistical result and the sources used, such as textbooks and references, he then drafted the questions. He submitted this to his adviser for evaluation to be sure of the questions' content and clarity. To ensure that all the respondents would understand the problem, the researcher conducted a dry-run of the instrument. Based on the respondents' feedback, the researcher prepared the final revision of the questionnaire.

\section{Ethical Considerations}

For ethical reasons, the researcher informs and educates the teacher-respondents about this study's purpose and objectives. Moreover, teacher-respondents could withdraw their participation in the study at any time they want. To ensure data privacy among all the respondents, the researcher treated personal information confidentially and anonymously. The teacher respondents had answered the evaluation in their own will. Any mode of resistance by the respondent was highly respected.

\section{Data-gathering Procedure}

To conduct this study, the researcher sought permission from the Schools Division Superintendent, Department of Education (DepEd). Division of Misamis Occidental, Oroquieta City. The approved request was sent to the Public Schools District Supervisor (PSDS) to distribute the questionnaire to the teacher respondents via Google Form to observe the health protocols during the COVID pandemic. Attached to the approved request was a letter addressed to each school administrator with the testing dates specified to avoid conflict of schedule

The researcher went to each school as scheduled. While in the office, a self-introduction was made and explained the study's purpose to gain their cooperation and establish rapport with them. Aside from the questionnaire given via Google Form, the researcher gave pointers and clarificatory dialogues to collect relevant data. The researcher electronically administered the questionnaire to ensure $100 \%$ retrieval.

\section{Data Analysis and Statistical Treatment}

- This study utilized four statistical techniques in the treatment of the data gathered.

- The researcher used frequency to determine the distribution of the data gathered.

- To determine the position of the respondents in each category, the researcher used percentages.

- In determining the overall results of the respondent's scores, the researcher employs means.

- In testing the significant relationship between the organization key behaviors of teachers and their instructional competence, the researcher used the chi-square of independence using the hereunder formula:

$$
E_{i j}=\frac{\sum_{k-1}^{c} o_{i j} \sum_{k-1}^{r} o_{k j}}{N}
$$

Where: 
$\mathrm{E}_{\mathrm{ij}}=$ Expected outcomes

$\sum_{k-1}^{c} o_{i j}=\sum$ of the $\mathrm{i}^{\text {th }}$ column

$\sum_{k-1}^{r} o_{k j}=\sum$ of the $\mathrm{k}^{\text {th }}$ column

$\mathrm{N}=$ Number of Cases

To determine the strength of association between significantly associated variables, the Cramer's V coefficient was applied using the formula:

$$
V=\sqrt{\frac{X^{2}}{k}}
$$

Where $\mathrm{X}^{2}$ chi-square and $\mathrm{k}$ is is the number of rows or columns in the table.

To test the internal consistency of the questionnaire, the Cronbach Coefficient Alpha was used.

$$
\alpha=\frac{N \cdot \bar{C}}{\bar{v}+(N-1) \cdot \bar{C}}
$$

Where:

$\mathrm{N}=$ Number of items

$\bar{C}=$ Average covariance between item - pairs

$\bar{v}=$ Average variance

\section{Chapter 3 - Results}

This chapter presents the results extracted from the statistical analysis made. All tabulated value was being generated through IBM SPSS software and the results gathered from the analysis of data adhere to the APA format in citing statistical inferences. Furthermore, the case summaries for the entire table presented herein were indicated in the appendix to ensure validity of results.

The presentation of results was divided into two parts namely: Part I Descriptives, Part 2 Inferential Statistics, to answer the following problem statement:

1. What are the levels of the organizational behaviors of teachers in terms of -

1.1 Communication,

1.2 Judgment and Decision Making,

1.3 Leadership Skills,

1.4 Teamwork and Cooperation,

1.5 Creativity and Innovation?

2. What is the level of the instructional competence of teachers in terms of - 
2.1 Planning and Preparation,

2.2 Instructional Process,

2.3 Assessment,

2.4 Professionalism,

2.5 Interpersonal Relationship,

2.6 Classroom Management?

3. Is there a significant relationship between organizational behavior and instructional competence towards a teacher's effectiveness?

\section{Part I - Descriptives}

This part showcases the result of descriptive analysis in the study. Tables were presented before the findings to give the readers a generalized concept on the descriptive result of the study.

Table 2 - Organizational Key Behavior in Communication (Descriptives)

\begin{tabular}{|c|c|c|c|c|c|}
\hline & $\mathbf{N}$ & Minimum & Maximum & Mean & Std. Deviation \\
\hline $\begin{array}{l}\text { Recognize And Understand The Perspective Of Other } \\
\text { People }\end{array}$ & 143 & 1.00 & 5.00 & 3.6713 & 1.05334 \\
\hline Receive Feedback And Learn From It & 143 & 1.00 & 5.00 & 3.7343 & 1.11930 \\
\hline Present Information To The Audience & 143 & 1.00 & 5.00 & 3.8042 & 1.01578 \\
\hline Great Written And Oral Skills & 143 & 1.00 & 5.00 & 3.6573 & 1.03533 \\
\hline $\begin{array}{l}\text { Initiate Dialogue And Involve People In The } \\
\text { Communication Process }\end{array}$ & 143 & 1.00 & 5.00 & 3.7692 & 1.01185 \\
\hline $\begin{array}{l}\text { Ability To Bring Value To People Y Presenting Them } \\
\text { Certain Information }\end{array}$ & 143 & 1.00 & 6.00 & 3.7343 & 1.02745 \\
\hline $\begin{array}{l}\text { Establishment Of Strong Connections With People } \\
\text { Through Communication }\end{array}$ & 143 & 1.00 & 5.00 & 3.5874 & 1.05703 \\
\hline $\begin{array}{l}\text { Presents An Open And Accepting Persona That } \\
\text { Allows The Most To Reluctant Person To Express } \\
\text { His/her Views }\end{array}$ & 143 & 1.00 & 5.00 & 3.6713 & 1.07321 \\
\hline $\begin{array}{l}\text { Encourages An Open Exchange Of Ideas And } \\
\text { Different Points Of View; Tells The Truth Even When } \\
\text { It Is Unwelcome }\end{array}$ & 143 & 2.00 & 5.00 & 3.6713 & 1.01243 \\
\hline $\begin{array}{l}\text { Demonstrates A Keen Ability To Recognize When } \\
\text { Others Are Having Difficulty Understanding His } \\
\text { Messages And Adapts Style Appropriately. }\end{array}$ & 143 & 1.00 & 5.00 & 3.6853 & 1.00295 \\
\hline Valid N (list wise) & 143 & & & & \\
\hline
\end{tabular}

\section{Findings:}

1. The organizational key behavior in "Recognize and Understand the Perspective of Other People" was perceived as High $(\mathrm{M}=3.61, \mathrm{SD}=1.05)$

2. The organizational key behavior in "Receive Feedback And Learn From It" was perceived as High $(\mathrm{M}=3.73, \mathrm{SD}=1.12)$

3. The organizational key behavior in "Present Information To The Audience" was perceived as $\operatorname{High}(\mathrm{M}=3.80, \mathrm{SD}=1.02)$ 
4. The organizational key behavior in "Great Writing and oral skills" was perceived as High (M = 3.66, $\mathrm{SD}=1.04$ )

5. The organizational key behavior in "initiate dialogue and involve people in the communication process" was perceived as high $(\mathrm{M}=3.77, \mathrm{SD}=1.01)$

6. The organizational key behavior in "ability to bring value to people presenting them certain information" was perceived as high $(\mathrm{M}=3.73, \mathrm{SD}=1.03)$

7. The organizational key behavior in "Establishment of strong connections with people through communication" was perceived as high $(\mathrm{M}=3.59, \mathrm{SD}=1.06)$

8. The organizational key behavior in "presents an open and accepting personal that allows the most to reluctant person to express his/her views" was perceived as high. $(\mathrm{M}=3.67, \mathrm{SD}=$ 1.07)

9. The organizational key behavior in "encourages an open exchange of ideas and different points of view; tells the truth even when it is unwelcome" was perceived as high $(\mathrm{M}=3.67, \mathrm{SD}=$ 1.01)

10. The organizational key behavior in "demonstrate a keen ability to recognize when others are having difficulty understanding his messages and adapts style appropriately" was perceived as high $(\mathrm{M}=3.69, \mathrm{SD}=1.003)$

Table 3 - Organizational Key Behavior in Judgement and Decision Making (Descriptive)

\begin{tabular}{|l|c|c|c|c|c|}
\hline & $\mathrm{N}$ & Minimum & Maximum & Mean & Std. Deviation \\
\hline $\begin{array}{l}\text { Demonstrate an ability to make effective decisions within } \\
\text { limited time. }\end{array}$ & 143 & 2.00 & 5.00 & 3.8462 & .75347 \\
\hline Develops highly creative and effective solutions despite & 143 & 2.00 & 5.00 & 3.9161 & .79165 \\
\hline $\begin{array}{l}\text { The teacher demonstrates maturity in dealing with } \\
\text { students. }\end{array}$ & 143 & 2.00 & 5.00 & 3.9301 & .79302 \\
\hline $\begin{array}{l}\text { The teacher seeks opportunities for his professional } \\
\text { development }\end{array}$ & 143 & 2.00 & 5.00 & 4.1049 & .71909 \\
\hline $\begin{array}{l}\text { The teacher demonstrates sound judgement in decision- } \\
\text { making }\end{array}$ & 143 & 2.00 & 5.00 & 3.9650 & .70624 \\
\hline $\begin{array}{l}\text { The teacher contributes to the life of the school including } \\
\text { co-curricular activities. }\end{array}$ & 143 & 2.00 & 5.00 & 4.0000 & .67135 \\
\hline $\begin{array}{l}\text { The teacher demonstrates leadership skills in the } \\
\text { performance of duties. }\end{array}$ & 143 & 2.00 & 5.00 & 3.9930 & .73635 \\
\hline The teachers adhere to the code of ethics. & 143 & 2.00 & 5.00 & 3.8601 & .81881 \\
\hline Valid N (list wise) & 143 & & & & \\
\hline
\end{tabular}

\section{Findings:}

1. The organizational key behavior in "demonstrate an ability to make an ability to make effective decisions within limited time" was perceived as high $(\mathrm{M}=3.85, \mathrm{SD}=0.75)$

2. The organizational key behavior in "develops highly creative and effective solutions despite pressure" was perceived as high $(\mathrm{M}=3.91, \mathrm{SD}=0.79)$

3. The organizational key behavior in "the teachers demonstrates maturity in dealing with students" was perceived as high $(\mathrm{M}=3.93, \mathrm{SD}=0.79)$

4. The organizational key behavior in "The teacher demonstrates maturity in dealing with students" was perceived as high $(\mathrm{M}=3.93, \mathrm{SD}=0.79)$ 
5. The organizational key behavior in "the teacher seeks opportunities for his professional development" was perceived as high $(\mathrm{M}=4.11, \mathrm{SD}=0.72)$

6. The organizational key behavior in "the teacher demonstrates sound judgement in decisionmaking" was perceived as high $(\mathrm{M}=3.97, \mathrm{SD}=0.71)$

7. The organizational key behavior in "the teacher demonstrates sound judgement and decisionmaking" was perceived as high $(\mathrm{M}=3.97, \mathrm{SD}=0.71)$

8. The organizational key behavior in "the teacher contributes to the life of the school including co-curricular activities" was perceived as high $(\mathrm{M}=4, \mathrm{SD}=0.67)$

9. The organizational key behavior in " the teacher demonstrates leadership skills in the performance of duties" was perceived as high $(\mathrm{M}=3.99, \mathrm{SD}=0.74)$

10. The organizational key behavior in "the teachers adhere to the code of ethics" was perceived as high $(\mathrm{M}=3.86, \mathrm{SD}=0.82)$

Table 4 - Organizational Key Behavior in Leadership Skills (Descriptives)

\begin{tabular}{|l|c|c|c|c|c|}
\hline & $\mathrm{N}$ & Minimum & Maximum & Mean & Std. Deviation \\
\hline $\begin{array}{l}\text { Encourages a sense of mutual accountability in class } \\
\text { settings that motivates students to do his best for each } \\
\text { other and exceed goals. }\end{array}$ & 143 & 1.00 & 5.00 & 4.0070 & .79165 \\
\hline $\begin{array}{l}\text { Identifies the most important priorities for the class and } \\
\text { focuses attention effectively. }\end{array}$ & 143 & 1.00 & 5.00 & 3.9720 & .89556 \\
\hline $\begin{array}{l}\text { Provides direction to less experienced teacher on how to } \\
\text { monitor the class without interfering student progress }\end{array}$ & 143 & 1.00 & 5.00 & 4.0420 & .78610 \\
\hline $\begin{array}{l}\text { Demonstrates an ability to identify underlying } \\
\text { performance issues among the class and delivery highly } \\
\text { insightful feedback. }\end{array}$ & 143 & 1.00 & 5.00 & 4.0909 & .73071 \\
\hline $\begin{array}{l}\text { Effective gives constructive feedback even when the } \\
\text { message is extremely difficult to deliver }\end{array}$ & 143 & 1.00 & 5.00 & 4.0000 & .87210 \\
\hline $\begin{array}{l}\text { Helps the students develop their ability to anticipate } \\
\text { problems by leveraging their past experiences so that } \\
\text { they can work independently }\end{array}$ & 143 & 1.00 & 5.00 & 3.9161 & .87610 \\
\hline $\begin{array}{l}\text { Positive influence on other teachers and students and } \\
\text { their motivation }\end{array}$ & 143 & 1.00 & 5.00 & 3.9510 & .89858 \\
\hline Ability to serve as an example and act correspondingly & 143 & 1.00 & 5.00 & 4.0000 & .81362 \\
\hline Ability to take responsibility and accountability. & 143 & 1.00 & 5.00 & 3.9650 & .79976 \\
\hline $\begin{array}{l}\text { Ability to encourage, coach, teach and assist other } \\
\text { people }\end{array}$ & 143 & 1.00 & 5.00 & 3.9650 & .81718 \\
\hline Valid N (list wise) & 143 & & & & \\
\hline
\end{tabular}

\section{Findings:}

1. The organizational key behavior in "encourages a sense of mutual accountability in class settings that motivates students to do his best for each other and exceed goals" was perceived as high $(\mathrm{M}=4, \mathrm{SD}=0.79)$

2. The organizational key behavior in "identifies the most important priorities for the class and focuses attention effectively" was perceived as high $(\mathrm{M}=3.97, \mathrm{SD}=0.89)$ 
3. The organizational key behavior in "provides direction to less experienced teacher on how to monitor the class without interfering student progress" was perceived as high $(\mathrm{M}=4.04, \mathrm{SD}=$ 0.79 )

4. The organizational key behavior in "demonstrates ability to identify underlying performance issues among the class and delivery highly insightful feedback" was perceived as high $(\mathrm{M}=$ 4.09, $\mathrm{SD}=0.73$ )

5. The organizational key behavior in "effective gives constructive feedback even when the message is extremely difficult to deliver" was perceived as high $(\mathrm{M}=4, \mathrm{SD}=0.87)$

6. The organizational key behavior in "helps the students develop their ability to anticipate problems by leveraging their past experiences so that they can work independently" was perceived as high $(\mathrm{M}=3.91, \mathrm{SD}=0.88)$

7. The organizational key behavior in "positive influence on other teachers and students and their motivation" was perceived as high $(\mathrm{M}=3.95, \mathrm{SD}=0.9)$

8. The organizational key behavior in " ability to serve as an example and act accordingly" was perceived as high $(\mathrm{M}=4, \mathrm{SD}=0.81)$

9. The organizational key behavior in "ability to take responsibility and accountability" was perceived as high $(\mathrm{M}=3.97, \mathrm{SD}=0.8)$

10. The organizational key behavior in "ability to encourage, coach, teach, and assist other people" was perceived as high $(\mathrm{M}=3.97, \mathrm{SD}=0.82)$

Table 5 - Organizational Key Behavior in Teamwork and Cooperation (Descriptives)

\begin{tabular}{|l|c|c|c|c|c|}
\hline & $\mathrm{N}$ & Minimum & Maximum & Mean & Std. Deviation \\
\hline $\begin{array}{l}\text { Frequently uses opportunities to work with others as a } \\
\text { teaching tool to impart organizational knowledge and } \\
\text { help others succeed. }\end{array}$ & 143 & 1.00 & 5.00 & 3.6923 & 1.05637 \\
\hline $\begin{array}{l}\text { Actively seeks to eliminate "cliques" and assists in } \\
\text { problem solving so that all teachers and students can be } \\
\text { included in work processes. }\end{array}$ & 143 & 1.00 & 5.00 & 3.5175 & 1.01989 \\
\hline $\begin{array}{l}\text { Builds loyalty among other teachers in the organization. } \\
\text { Provides guidance to others as they work through } \\
\text { conflicts and disagreements so they can become better } \\
\text { "team players". }\end{array}$ & 143 & 1.00 & 5.00 & 3.6573 & 1.11396 \\
\hline $\begin{array}{l}\text { Facilitates communication between people experiencing } \\
\text { conflict who have previously been unable to solve } \\
\text { problems }\end{array}$ & 143 & 1.00 & 5.00 & 3.5804 & 1.09681 \\
\hline $\begin{array}{l}\text { Volunteers on committees that are outside typical job } \\
\text { responsibilities; exceeds the expectations of his job in } \\
\text { participating in school initiatives and programs. }\end{array}$ & 143 & 1.00 & 5.00 & 3.6783 & .98296 \\
\hline $\begin{array}{l}\text { Proactively works with teachers and students to improve } \\
\text { collaboration and functioning on a continuous basis. }\end{array}$ & 143 & 1.00 & 5.00 & 3.7483 & 1.00329 \\
\hline \begin{tabular}{l} 
Valid N (list wise) \\
\hline
\end{tabular} & 143 & & & & \\
\hline
\end{tabular}

\section{Findings:}

1. The organizational key behavior in "frequently uses opportunities to work with others as a teaching tool to impact organizational knowledge and help others succeed" was perceived as high $(\mathrm{M}=3.69, \mathrm{SD}=1.06)$ 
2. The organizational key behavior in "actively seeks to eliminate "cliques" and assists in problem solving so that all teachers and students can be included in work process" was perceived as high $(\mathrm{M}=3.52, \mathrm{SD}=1.02)$

3. The organizational key behavior in "builds loyalty among other teachers in the organization" was perceived as high $(\mathrm{M}=3.65, \mathrm{SD}=1.06)$

4. The organizational key behavior in "provides guidance to others as they work through conflicts and disagreements so they can become better "team players" was perceived as high $(\mathrm{M}=3.66$, $\mathrm{SD}=1.11)$

5. The organizational key behavior in "Facilitates communication between people experiencing conflict who have previously been unable to solve problems" was perceived as high $(\mathrm{M}=3.58$, $\mathrm{SD}=1.1)$

6. The organizational key behavior in "volunteers on committees that are outside typical job responsibilities; exceeds the expectations of his job in participating in school initiatives and programs was perceived as high $(\mathrm{M}=3.68, \mathrm{SD}=0.98)$

7. The organizational key behavior in "proactively work with teachers and students to improve collaboration and functioning basis" was perceived as high $(\mathrm{M}=3.75, \mathrm{SD}=1)$

Table 6 - Organizational Key Behavior in Creativity and Innovation (Descriptive)

\begin{tabular}{|c|c|c|c|c|c|}
\hline & $\mathbf{N}$ & Minimum & Maximum & Mean & Std. Deviation \\
\hline $\begin{array}{l}\text { Takes "smart" risks including trying new and different } \\
\text { ways to get the job done }\end{array}$ & 143 & 1.00 & 5.00 & 3.9021 & .88266 \\
\hline $\begin{array}{l}\text { Relentlessly challenges the status quo to ensure area } \\
\text { for improvement are identified and addressed }\end{array}$ & 143 & 1.00 & 5.00 & 3.8322 & .85569 \\
\hline $\begin{array}{l}\text { Inspires others to develop and implement new ideas } \\
\text { and ways to approach to work hat benefit the State } \\
\text { and its customers. }\end{array}$ & 143 & 1.00 & 5.00 & 4.0070 & .89989 \\
\hline $\begin{array}{l}\text { Champions innovative approaches within the } \\
\text { department by acting as an opinion leader whom } \\
\text { others emulate }\end{array}$ & 143 & 1.00 & 5.00 & 4.0909 & .82998 \\
\hline $\begin{array}{l}\text { Encourages new ideas, and motivates others to be } \\
\text { proactive, resourceful, and know the customer }\end{array}$ & 143 & 1.00 & 5.00 & 4.0280 & .79562 \\
\hline $\begin{array}{l}\text { Creates and implements customized processes and } \\
\text { practices that demonstrate "best practices" for the } \\
\text { school. }\end{array}$ & 143 & 1.00 & 5.00 & 3.9091 & .89529 \\
\hline $\begin{array}{l}\text { Identifies and visualizes options and formulates } \\
\text { innovative approaches }\end{array}$ & 143 & 1.00 & 5.00 & 4.2517 & 0.9756 \\
\hline $\begin{array}{l}\text { Foster an environment that supports the smooth } \\
\text { implementation of new approaches/programs }\end{array}$ & 143 & 1.00 & 5.00 & 3.8811 & .89198 \\
\hline $\begin{array}{l}\text { Develops creative and highly effective ways of doing } \\
\text { work/services provided by the school. }\end{array}$ & 143 & 1.00 & 5.00 & 3.9720 & .84707 \\
\hline $\begin{array}{l}\text { Generates support among co-workers for even the } \\
\text { most controversial ideas and concepts. }\end{array}$ & 143 & 1.00 & 5.00 & 3.9720 & .87969 \\
\hline Valid N (list wise) & 143 & & & & \\
\hline
\end{tabular}




\section{Findings:}

1. The organizational key behavior in "takes smart risks including trying new and different ways to get the job done" was perceived as high $(\mathrm{M}=3.9, \mathrm{SD}=0.88)$

2. The organizational key behavior in "relentlessly challenges the status quo ensure area for improvement are identified and addressed" was perceived as high $(\mathrm{M}=3.83, \mathrm{SD}=0.86)$

3. The organizational key behavior in "inspires others to develop and implement new ideas and ways to approach to work what benefit the State and its customers" was perceived as high ( $\mathrm{M}=$ $4, \mathrm{SD}=0.9$ )

4. The organizational key behavior in "Champions innovative approaches within the department by acting as an opinion leader whom others emulate" was perceived as high $(\mathrm{M}=4, \mathrm{SD}=$ 0.83 )

5. The organizational key behavior in "encourages new ideas, and motivates others to be proactive, resourceful, and know the customer" was perceived as high $(\mathrm{M}=4.02, \mathrm{SD}=0.8)$

6. The organizational key behavior in "creates and implements customized processes and practices that demonstrate best practices for the school" was perceived as high $(\mathrm{M}=3.9, \mathrm{SD}=$ 0.9)

7. The organizational key behavior in "identifies and visualizes options and formulates innovative approaches" was perceived as Very high $(\mathrm{M}=4.25, \mathrm{SD}=4.25)$.

8. The organizational key behavior in "foster an environment that supports the smooth implementation of new approaches/programs" was perceived as high $(\mathrm{M}=3,88, \mathrm{SD}=0.89)$

9. The organizational key behavior in "develops creative and highly effective ways of doing work/services provided by the school" was perceived as high $(\mathrm{M}=3.97, \mathrm{SD}=0.85)$

10. The organizational key behavior in "generates support among co-workers for even the most controversial ideas and concepts" was perceived as high $(\mathrm{M}=3.97, \mathrm{SD}=0.88)$

Table 7 Instructional Competence in Relation to Teachers Planning and Preparation (Descriptives)

\begin{tabular}{|l|c|c|c|c|c|}
\hline & $\mathrm{N}$ & Minimum & Maximum & Mean & Std. Deviation \\
\hline $\begin{array}{l}\text { The teacher prepares lesson plans that are well laid out } \\
\text { and sequenced. }\end{array}$ & 143 & 1.00 & 5.00 & 3.7483 & .81766 \\
\hline The teacher writes objectives that are SMART. & 143 & 1.00 & 5.00 & 3.7622 & .77785 \\
\hline The teacher writes objectives that are level appropriate & 143 & 1.00 & 5.00 & 3.7972 & .88461 \\
\hline $\begin{array}{l}\text { The teachers prepare content that is a good match for } \\
\text { the objectives. }\end{array}$ & 143 & 1.00 & 5.00 & 3.7552 & .98736 \\
\hline The teacher plans activities that are well differentiated. & 143 & 1.00 & 5.00 & 3.7413 & .86978 \\
\hline $\begin{array}{l}\text { The teacher prepares instruction with opportunities for } \\
\text { individual work. }\end{array}$ & 143 & 1.00 & 5.00 & 3.8322 & .81350 \\
\hline $\begin{array}{l}\text { The teacher prepares instructional materials that are } \\
\text { adequate. }\end{array}$ & 143 & 1.00 & 5.00 & 3.9301 & .88533 \\
\hline $\begin{array}{l}\text { The teacher include timing as an integral part of } \\
\text { planning }\end{array}$ & 143 & 1.00 & 5.00 & 3.9231 & .79680 \\
\hline The teacher is well organized for lesson presentation & 142 & 1.00 & 5.00 & 3.9085 & .82432 \\
\hline $\begin{array}{l}\text { The teacher prepares assessment exercises to monitor } \\
\text { students' learning }\end{array}$ & 143 & 1.00 & 5.00 & 3.8462 & .88260 \\
\hline \begin{tabular}{l} 
Valid N (listwise) \\
\hline
\end{tabular}
\end{tabular}




\section{Findings:}

1. The Instructional Competence in "the teachers prepares lesson plans that are well laid out and sequenced" was perceived as Good $(\mathrm{M}=3.75, \mathrm{SD}=0.82)$

2. The Instructional Competence in "the teacher writes objectives that are SMART" was perceived as Good $(\mathrm{M}=3.76, \mathrm{SD}=3.78)$

3. The Instructional Competence in "the teacher writes objectives that are level appropriate" was perceived as Good $(\mathrm{M}=3.79, \mathrm{SD}=0.88)$

4. The Instructional Competence in "the teachers prepare content that is a good match for the objectives" was perceived as Good $(\mathrm{M}=3.76, \mathrm{SD}=0.99)$

5. The Instructional Competence in " the teacher plans activities that are well differentiated' was perceived as Good $(\mathrm{M}=3.74, \mathrm{SD}=0.87)$

6. The Instructional Competence in " the teacher prepares instruction with opportunities for individual work was perceived as $\operatorname{Good}(\mathrm{M}=3.83, \mathrm{SD}=0.81)$

7. The instructional competence in " the teacher prepares instructional materials that are adequate was perceived as $\operatorname{good}(\mathrm{M}=3.93, \mathrm{SD}=0.89)$

8. The instructional competence in "the teacher include timing as an integral part of planning" was perceived as Good $(\mathrm{M}=3.92, \mathrm{SD}=0.8)$

9. The instructional competence in "the teacher is well organized for lesson presentation" was perceived as Good $(\mathrm{M}=3.81, \mathrm{SD}=0.82)$

10. The instructional competence in " the teacher prepares assessment exercises to monitor student's learning was perceived as $\operatorname{Good}(\mathrm{M}=3.84, \mathrm{SD}=0.88)$

Table 8 - Instructional Competence in Relation to Instructional Process (Descriptives)

\begin{tabular}{|l|c|c|c|c|c|}
\hline & $\mathrm{N}$ & Minimum & Maximum & Mean & Std. Deviation \\
\hline $\begin{array}{l}\text { The teacher makes objectives explicit to students at the } \\
\text { start of the lesson. }\end{array}$ & 143 & 1.00 & 5.00 & 3.5874 & .85850 \\
\hline $\begin{array}{l}\text { The teacher engages students in activities that are } \\
\text { appropriate and meaningful. }\end{array}$ & 143 & 1.00 & 5.00 & 3.6154 & .92632 \\
\hline $\begin{array}{l}\text { The teacher engages students in activities that encourage } \\
\text { them to think. }\end{array}$ & 143 & 1.00 & 5.00 & 3.5804 & .90704 \\
\hline $\begin{array}{l}\text { The teacher uses a variety of teaching strategies to } \\
\text { enhance learning. }\end{array}$ & 143 & 1.00 & 5.00 & 3.6853 & .96721 \\
\hline The teacher arouses and maintains students' interest. & 143 & 1.00 & 5.00 & 3.6573 & .89682 \\
\hline $\begin{array}{l}\text { The teacher uses appropriate instructional materials in the } \\
\text { teaching. }\end{array}$ & 143 & 1.00 & 5.00 & 3.5105 & .94844 \\
\hline The teacher uses appropriate questioning techniques. & 143 & 1.00 & 5.00 & 3.6014 & 1.01496 \\
\hline $\begin{array}{l}\text { The teacher ensures that all students participate in } \\
\text { instructional activities. }\end{array}$ & 143 & 1.00 & 5.00 & 3.6084 & .93474 \\
\hline $\begin{array}{l}\text { The teacher guides students to develop concepts/master } \\
\text { skills. }\end{array}$ & 143 & 1.00 & 5.00 & 3.6154 & .93389 \\
\hline $\begin{array}{l}\text { The teacher presents instruction in a logical and coherent } \\
\text { manner. }\end{array}$ & 143 & 1.00 & 5.00 & 3.5315 & .93300 \\
\hline Valid N (list wise) & 143 & & & & \\
\hline
\end{tabular}




\section{Findings:}

1. The Instructional Competence in "teacher makes objectives explicit to students at the start of the lesson was perceived as $\operatorname{good}(\mathrm{M}=3.58, \mathrm{SD}=0.86)$

2. The instructional competence in "the teacher engages students in activities that are appropriate and meaningful" was perceived as Good $(\mathrm{M}=3.62, \mathrm{SD}=0.92)$

3. The instructional competence in "the teacher engages students in activities that encourage them to think" was perceived as good $(\mathrm{M}=3.58, \mathrm{SD}=0.92)$

4. The instructional competence in "the teacher uses a variety of teaching strategies to enhance learning" was perceived as good $(\mathrm{M}=3.69, \mathrm{SD}=0.97)$

5. The instructional competence in "the teacher arouses and maintains students' interest" was perceived as good $(\mathrm{M}=3.66, \mathrm{SD}=0.9)$

6. The instructional competence in "the teacher uses appropriate instructional materials in teaching" was perceived as good $(\mathrm{M}=3.51, \mathrm{SD}=0.95)$

7. The instructional competence in "the teacher uses appropriate techniques" was perceived as $\operatorname{good}(\mathrm{M}=3.6, \mathrm{SD}=1.01)$

8. The instructional competence in "the teacher ensures that all students participate in instructional activities" was perceives as $\operatorname{good}(\mathrm{M}=3.61, \mathrm{SD}=0.93)$

9. The instructional competence in "the teacher guides students to develop concepts/master skills" was perceived as $\operatorname{good}(\mathrm{M}=3.62, \mathrm{SD}=93)$

10. The instructional competence in "the teacher presents instruction in a logical and coherent manner" was perceived as good $(\mathrm{M}=3.53, \mathrm{SD}=0.93)$

Table 9 - Instructional Competence in Relation to Assessment (Descriptives)

\begin{tabular}{|l|c|c|c|c|c|}
\hline & $\mathrm{N}$ & Minimum & Maximum & Mean & Std. Deviation \\
\hline $\begin{array}{l}\text { The teacher uses appropriate assessment activities to } \\
\text { monitor student performance. }\end{array}$ & 143 & 1.00 & 5.00 & 3.8252 & .98091 \\
\hline $\begin{array}{l}\text { The teacher provides corrective feedback during the } \\
\text { course of the lesson. }\end{array}$ & 143 & 1.00 & 5.00 & 3.8182 & .95413 \\
\hline $\begin{array}{l}\text { The teacher provides timely feedback to students on their } \\
\text { performance. }\end{array}$ & 143 & 1.00 & 5.00 & 3.7762 & .89929 \\
\hline $\begin{array}{l}\text { The teacher provides timely feedback to parents on } \\
\text { students' performance. }\end{array}$ & 143 & 1.00 & 5.00 & 3.8392 & .95424 \\
\hline $\begin{array}{l}\text { The teacher takes appropriate action based on results of } \\
\text { assessment. }\end{array}$ & 143 & 1.00 & 5.00 & 3.8252 & 1.00221 \\
\hline Valid N (list wise) & 143 & & & & \\
\hline
\end{tabular}

\section{Findings:}

1. The Instructional Competence in "the teacher uses appropriate assessment activities to monitor student performance" was perceived as good $(\mathrm{M}=3.83, \mathrm{SD}=0.98)$

2. The instructional competence in "the teacher provides corrective feedback during the course of the lesson" was perceived as good $(\mathrm{M}=3.82, \mathrm{SD}=0.95)$

3. The instructional competence in "the teacher provides timely feedback to students on their performance" was perceived as good $(\mathrm{N}=3.78, \mathrm{SD}=0.9)$

4. The instructional competence in "the teacher provides timely feedback to parents on students' performance was perceived as good $(\mathrm{M}=3.83, \mathrm{SD}=0.95)$ 
5. The instructional competence in " the teacher takes appropriate action based on results of assessment" was perceived as good $(\mathrm{M}=3.83, \mathrm{SD}=1)$

Table 10 - Instructional Competence in Relation to Professionalism (Descriptives)

\begin{tabular}{|l|c|c|c|c|c|}
\hline & $\mathrm{N}$ & Minimum & Maximum & Mean & Std. Deviation \\
\hline $\begin{array}{l}\text { The teacher expresses himself clearly and is easily } \\
\text { understood. }\end{array}$ & 143 & 1.00 & 5.00 & 3.5035 & .99911 \\
\hline The teacher reports for work regularly. & 143 & 1.00 & 5.00 & 3.4965 & .97774 \\
\hline $\begin{array}{l}\text { The teacher demonstrates maturity in dealing with } \\
\text { students. }\end{array}$ & 143 & 1.00 & 5.00 & 3.5664 & .99689 \\
\hline $\begin{array}{l}\text { The teacher seeks opportunities for his professional } \\
\text { development }\end{array}$ & 143 & 1.00 & 5.00 & 3.4685 & 1.04007 \\
\hline $\begin{array}{l}\text { The teacher demonstrates sound judgement in decision } \\
\text { making. }\end{array}$ & 143 & 1.00 & 5.00 & 3.7133 & 1.04396 \\
\hline $\begin{array}{l}\text { The teacher contributes to the life of the school } \\
\text { including co-curricular activities. }\end{array}$ & 143 & 1.00 & 5.00 & 3.7413 & 1.00030 \\
\hline $\begin{array}{l}\text { The teacher demonstrates leadership skills in the } \\
\text { performance of duties. }\end{array}$ & 143 & 1.00 & 5.00 & 3.4406 & 1.05898 \\
\hline The teacher adhere to the code of ethics. & 143 & 1.00 & 5.00 & 3.4965 & 1.05399 \\
\hline Valid N (list wise) & 143 & & & & \\
\hline
\end{tabular}

\section{Findings:}

1. The Instructional Competence in "the teacher expresses himself clearly and easily understood" was perceived as good $(\mathrm{M}=3.5, \mathrm{SD}=1)$

2. The instructional competence in "the teacher reports for work regularly" was perceived as good $(\mathrm{M}=3.5, \mathrm{SD}=1)$

3. The instructional competence in " the teacher demonstrates maturity in dealing with students" was perceived as good $(\mathrm{M}=3.6, \mathrm{SD}=1)$

4. The instructional competence in "the teacher seeks opportunities for his professional development" was perceived as good $(\mathrm{M}=3.47, \mathrm{SD}=1.04)$

5. The instructional competence in "the teacher demonstrates sound judgement in decision making" was perceived as good $(\mathrm{M}=3.71, \mathrm{SD}=1.04)$

6. The instructional competence in "the teacher contributes to the life of the school including cocurricular activities" was perceived as $\operatorname{good}(\mathrm{M}=3.74, \mathrm{SD}=1)$

7. The instructional competence in " the teacher demonstrates leadership skills in the performance of duties" was perceived as good $(\mathrm{M}=3.44, \mathrm{SD}=1.05)$

8. The instructional competence in "the teacher adhere to the code of ethics" was perceived as $\operatorname{good}(\mathrm{M}=3.5, \mathrm{SD}=1.05)$

Table 11 - Instructional Competence in Relation to Interpersonal Relationship (Descriptives)

\begin{tabular}{|l|c|c|c|c|c|}
\hline & $\mathrm{N}$ & Minimum & Maximum & Mean & Std. Deviation \\
\hline $\begin{array}{l}\text { The teacher encourages student to respect the worth and } \\
\text { dignity of others. }\end{array}$ & 143 & 1.00 & 5.00 & 3.6154 & .94140 \\
\hline $\begin{array}{l}\text { The teacher offers advice to others principal, colleagues, } \\
\text { students and parents }\end{array}$ & 143 & 1.00 & 5.00 & 3.6434 & .93752 \\
\hline
\end{tabular}




\begin{tabular}{|l|c|c|c|c|c|}
\hline $\begin{array}{l}\text { The teacher accepts advice from others principal, } \\
\text { colleagues, students and parents. }\end{array}$ & 143 & 1.00 & 5.00 & 3.5944 & .98035 \\
\hline $\begin{array}{l}\text { The teacher demonstrates sensitivity to opinions, and } \\
\text { attitudes and feelings of others. }\end{array}$ & 143 & 1.00 & 5.00 & 3.6923 & .81561 \\
\hline $\begin{array}{l}\text { Communicates effectively with students, colleagues, } \\
\text { and parents. }\end{array}$ & 143 & 1.00 & 5.00 & 3.5874 & .92179 \\
\hline $\begin{array}{l}\text { Maintains a good rapport with students, colleagues, and } \\
\text { parent. }\end{array}$ & 143 & 1.00 & 5.00 & 3.5385 & .89418 \\
\hline Valid N (list wise) & 143 & & & & \\
\hline
\end{tabular}

\section{Findings:}

1. The Instructional Competence in "the teacher encourages student to respect the worth and dignity of others" was perceived as good $(\mathrm{M}=3.61, \mathrm{SD}=0.94)$

2. The Instructional competence in " the teacher offers advice to other principal, colleagues, students and parents" was perceived as good $(\mathrm{M}=3.64, \mathrm{SD}=0.93)$

3. The instructional competence in "the teacher accepts advice from others, principal, colleagues, students and parents was perceived as $\operatorname{good}(\mathrm{M}=3.6, \mathrm{SD}=0.98)$

4. The instructional competence in " the teacher is cooperative and works well with staff members" was perceived as good $(\mathrm{M}=3.56, \mathrm{SD}=0.91)$

5. The instructional competence in " the teacher demonstrates sensitivity to opinions and attitudes and feelings of others" was perceived as $\operatorname{good}(\mathrm{M}=3.62, \mathrm{SD}=0.82)$

6. The instructional competence in "communicates effectively with students colleagues, and parents" was perceived as good $(\mathrm{M}=3.59, \mathrm{SD}=0.92)$

7. The instructional competence in Maintains a good rapport with students colleagues and parents" was perceived as $\operatorname{good}(\mathrm{M}=3.54, \mathrm{SD}=0.89)$

\section{Table 12 - Instructional Competence in Relation to Classroom Management (Descriptives)}

\begin{tabular}{|l|c|c|c|c|c|}
\hline & $\mathrm{N}$ & Minimum & Maximum & Mean & Std. Deviation \\
\hline $\begin{array}{l}\text { The teacher demonstrates an awareness of what is } \\
\text { happening in the classroom. }\end{array}$ & 143 & 1.00 & 5.00 & 3.6364 & .94605 \\
\hline The teacher deals effectively with students' behavior. & 143 & 1.00 & 5.00 & 3.7203 & 1.01680 \\
\hline The teacher is fair in dealing with students. & 143 & 1.00 & 5.00 & 3.6294 & .99773 \\
\hline The teacher manages time effectively. & 143 & 1.00 & 5.00 & 3.6014 & .96517 \\
\hline $\begin{array}{l}\text { The teacher manages and utilizes learning resources } \\
\text { effectively. }\end{array}$ & 143 & 1.00 & 5.00 & 3.6154 & 1.01345 \\
\hline $\begin{array}{l}\text { The teacher manages effectively, classroom-related } \\
\text { activities, assignments, projects and field trips. }\end{array}$ & 143 & 1.00 & 5.00 & 3.5175 & .96307 \\
\hline $\begin{array}{l}\text { The teacher ensures that students observe the rules for } \\
\text { classroom activities and students' behavior. }\end{array}$ & 143 & 1.00 & 5.00 & 3.4615 & 1.04659 \\
\hline $\begin{array}{l}\text { The teacher demonstrates effective transition from one } \\
\text { activity }\end{array}$ & 143 & 1.00 & 5.00 & 3.4965 & .99204 \\
\hline The teacher keeps accurate and relevant student records & 143 & 1.00 & 5.00 & 3.5524 & .93205 \\
\hline Valid N (list wise) & 143 & & & & \\
\hline
\end{tabular}




\section{Part II. Statistical Inference}

This part presents the relationship between the identified variables for instruction competence and organizational key behavior. The responses for variables, organizational behavior and instructional competence was being categorized into nominal scale to ensure that only categorical data was being analyzed in the cross tabulations performed through Chi-Square test of relationship. The categorization of data was further indicated below:

For the Organizational key Behavior, the respondents' perception was categorized into two nominal classifications namely; High (for responses inclusive in $5=$ Very High and $4=$ High); Low (for responses inclusive in 3 = Average, 2 = Low, 1 = Very Low) and instructional competence was subgrouped into Good (for responses inclusive in $5=$ Very Good and $4=$ Good) and Below Average (for responses inclusive in $3=$ Good, 2 = Below Average, 1 = Unsatisfactory).

NOTE: Neutral responses were embedded in the lower-subgroup to avoid biases that would possibly occur in the conduct of chi-square test.

Table 13 - Case Processing Summary (Communication * Instructional Competence)

\begin{tabular}{|c|c|c|c|c|c|c|}
\hline & \multicolumn{6}{|c|}{ Cases } \\
\hline & \multicolumn{2}{|c|}{ Valid } & \multicolumn{2}{|c|}{ Missing } & \multicolumn{2}{|c|}{ Total } \\
\hline & $\mathbf{N}$ & Percent & $\mathbf{N}$ & Percent & $\mathbf{N}$ & Percent \\
\hline Planning * Communication & 143 & $100 \%$ & 0 & $0 \%$ & 143 & $100 \%$ \\
\hline Instructional Process * Communication & 143 & $100 \%$ & 0 & $0 \%$ & 143 & $100 \%$ \\
\hline Assessment $*$ Communication & 143 & $100 \%$ & 0 & $0 \%$ & 143 & $100 \%$ \\
\hline Professionalism * Communication & 143 & $100 \%$ & 0 & $0 \%$ & 143 & $100 \%$ \\
\hline International $*$ Communication & 143 & $100 \%$ & 0 & $0 \%$ & 143 & $100 \%$ \\
\hline Classroom * Communication & 143 & $100 \%$ & 0 & $0 \%$ & 143 & $100 \%$ \\
\hline
\end{tabular}

Table 13 presents the summary of the cross tabulations for communication and the identified factors for instructional competence. It can be incurred that there are 143 cases per cross tabulation and there is no missing cases for each cross tabulations being made.

\subsection{Planning * Communication}

Chi-Square Tests

\begin{tabular}{|l|c|c|c|c|c|}
\hline & Value & Df & $\begin{array}{c}\text { Asymptotic Significance } \\
\text { (2-sided) }\end{array}$ & $\begin{array}{c}\text { Exact Sig. } \\
\text { (2-sided) }\end{array}$ & $\begin{array}{c}\text { Exact Sig. } \\
\text { (1-sided) }\end{array}$ \\
\hline Pearson Chi-Square & $1.000^{\mathrm{a}}$ & 1 & .317 & & \\
\hline Continuity Correction & .315 & 1 & .575 & & \\
\hline Likelihood Ratio & .911 & 1 & .340 & & .383 \\
\hline Fisher's Exact Test & & & & .319 & .274 \\
\hline Linear-by-Linear Association & .993 & 1 & & & \\
\hline N of Valid Cases & 143 & & & & \\
\hline a. 1 cells (25\%) have expected count less than 5. The minimum expected count is 1.86. \\
\hline \\
\hline
\end{tabular}




\section{Findings:}

The relationship between planning and communication was not significant: $X^{2}(1, N=143)=1, p=$ 0.317

\subsubsection{Instructional Process * Communication}

\section{Chi-Square Tests}

\begin{tabular}{|c|c|c|c|c|c|}
\hline & Value & Df & $\begin{array}{c}\text { Asymptotic Significance } \\
\text { (2-sided) }\end{array}$ & $\begin{array}{l}\text { Exact Sig. } \\
\text { (2-sided) }\end{array}$ & $\begin{array}{l}\text { Exact Sig. } \\
\text { (1-sided) }\end{array}$ \\
\hline Pearson Chi-Square & $37.273^{\mathrm{a}}$ & 1 & .000 & & \\
\hline Continuity Correction & 34.899 & 1 & .000 & & \\
\hline Likelihood Ratio & 36.917 & 1 & .000 & & \\
\hline Fisher's Exact Test & & & & .000 & .000 \\
\hline Linear-by-Linear Association & 37.013 & 1 & .000 & & \\
\hline $\mathrm{N}$ of Valid Cases & 143 & & & & \\
\hline
\end{tabular}

\subsubsection{Symmetric Measures}

\begin{tabular}{|l|l|c|c|}
\hline \multicolumn{2}{|c|}{} & Value & Approximate Significance \\
\hline \multirow{2}{*}{ Nominal by Nominal } & Phi & .511 & .000 \\
\cline { 2 - 4 } & Cramer's V & .511 & .000 \\
\hline N of Valid Cases & 143 & \\
\hline
\end{tabular}

\section{Findings:}

There is a significant relationship between instructional process and communication $X^{2}(1, N=143)$ $=37.27, \mathrm{p}<0.05 \mathrm{~V}_{\text {Cramer }}=0.51$. As indicated in table 13.2.2 the strength of association between the variables have exceeded the minimum threshold of 0.10 which implies that there is a substantial evidence to conclude that teachers' skill in communication will greatly enhance the instructional process.

\subsection{Assessment * Communication}

Chi-Square Tests

\begin{tabular}{|l|c|c|c|c|c|}
\hline & Value & Df & $\begin{array}{c}\text { Asymptotic Significance } \\
\text { (2-sided) }\end{array}$ & $\begin{array}{c}\text { Exact Sig. } \\
\text { (2-sided) }\end{array}$ & $\begin{array}{c}\text { Exact Sig. } \\
\text { (1-sided) }\end{array}$ \\
\hline Pearson Chi-Square & $.123^{\mathrm{a}}$ & 1 & .726 & & \\
\hline Continuity Correction & .015 & 1 & .904 & & \\
\hline Likelihood Ratio & .121 & 1 & .728 & .819 & \\
\hline Fisher's Exact Test & & & & .727 & \\
\hline Linear-by-Linear Association & .122 & 1 & & & \\
\hline N of Valid Cases & 143 & & & & \\
\hline a. 0 cells (0\%) have expected count less than 5. The minimum expected count is 8.24. & \\
\hline b. Computed only for a 2 2 table & \\
\hline
\end{tabular}




\section{Findings:}

The relationship between assessment and communication was not significant: $X^{2}(1, N=143)=$ $0.123, \mathrm{p}>0.05$.

\subsubsection{Professionalism * Communication}

Chi-Square Tests

\begin{tabular}{|c|c|c|c|c|c|}
\hline & Value & Df & $\begin{array}{c}\text { Asymptotic Significance } \\
\text { (2-sided) }\end{array}$ & $\begin{array}{l}\text { Exact Sig. } \\
\text { (2-sided) }\end{array}$ & $\begin{array}{l}\text { Exact Sig. } \\
\text { (1-sided) }\end{array}$ \\
\hline Pearson Chi-Square & $5.324^{\mathrm{a}}$ & 1 & .021 & & \\
\hline Continuity Correction & 4.439 & 1 & .035 & & \\
\hline Likelihood Ratio & 5.713 & 1 & .017 & & \\
\hline Fisher's Exact Test & & & & .027 & .015 \\
\hline Linear-by-Linear Association & 5.286 & 1 & .021 & & \\
\hline $\mathrm{N}$ of Valid Cases & 143 & & & & \\
\hline \multicolumn{6}{|c|}{ a. 0 cells $(0 \%)$ have expected count less than 5 . The minimum expected count is 12.76 . } \\
\hline b. Computed only for a $2 \times 2 \mathrm{t}$ & & & & & \\
\hline
\end{tabular}

\subsubsection{Symmetric Measures}

\begin{tabular}{|l|l|c|c|}
\hline \multicolumn{2}{|c|}{} & Value & Approximate Significance \\
\hline \multirow{2}{*}{ Nominal by Nominal } & Phi & -.193 & .021 \\
\cline { 2 - 4 } & Cramer's V & .193 & .021 \\
\hline N of Valid Cases & 143 & \\
\hline
\end{tabular}

\section{Findings:}

There is a significant relationship between instructional process and communication: $\mathrm{X}^{2}(1, \mathrm{~N}=$ $143)=5.324, \mathrm{p}<0.05 \mathrm{~V}_{\text {Cramer }}=0.19$. As indicated in table 14.2.2, the strength of association between the variables have exceeded the minimum threshold of 0.10 , it can be further generalized that the two association between the two variables is moderately strong, thus competence in communication will greatly affect teachers' professionalism.

\subsection{Interpersonal Relationship * Communication}

Chi-Square Tests

\begin{tabular}{|l|c|c|c|c|c|}
\hline & Value & Df & $\begin{array}{c}\text { Asymptotic Significance } \\
\text { (2-sided) }\end{array}$ & $\begin{array}{c}\text { Exact Sig. } \\
\text { (2-sided) }\end{array}$ & $\begin{array}{c}\text { Exact Sig. } \\
\text { (1-sided) }\end{array}$ \\
\hline Pearson Chi-Square & $2.797^{\mathrm{a}}$ & 1 & .094 & & \\
\hline Continuity Correction & 2.126 & 1 & .145 & & \\
\hline Likelihood Ratio & 2.685 & 1 & .101 & .132 & .074 \\
\hline Fisher's Exact Test & & & & .096 & \\
\hline Linear-by-Linear Association & 2.777 & 1 & & & \\
\hline N of Valid Cases & 143 & & & & \\
\hline \\
\hline
\end{tabular}




\section{Findings:}

The relationship between interpersonal relationship and communication was not significant: $\mathrm{X}^{2}(1$, $\mathrm{N}=143)=2.797, \mathrm{p}>0.05$.

\subsection{Classroom Management * Communication}

\section{Chi-Square Tests}

\begin{tabular}{|l|c|c|c|c|c|}
\hline & Value & Df & $\begin{array}{c}\text { Asymptotic Significance } \\
\text { (2-sided) }\end{array}$ & $\begin{array}{c}\text { Exact Sig. } \\
\text { (2-sided) }\end{array}$ & $\begin{array}{c}\text { Exact Sig. } \\
\text { (1-sided) }\end{array}$ \\
\hline Pearson Chi-Square & $.015^{\mathrm{a}}$ & 1 & .902 & & \\
\hline Continuity Correction & .000 & 1 & 1.000 & & \\
\hline Likelihood Ratio & .015 & 1 & .903 & & \\
\hline Fisher's Exact Test & & & & 1.000 & .598 \\
\hline Linear-by-Linear Association & .015 & 1 & .903 & & \\
\hline N of Valid Cases & 143 & \multicolumn{5}{l|}{} \\
\hline \\
a. 1 cells (25\%) have expected count less than 5. The minimum expected count is 1.86. \\
\hline \\
b. Computed only for a 2 2 2 table \\
\hline
\end{tabular}

\section{Findings:}

The relationship between Classroom Management and communication was not significant: $X^{2}(1, N$ $=143)=0.15, \mathrm{p}>0.05$.

Table 14 - Case Processing Summary (Judgement * Instructional Competence)

\begin{tabular}{|c|c|c|c|c|c|c|}
\hline & \multicolumn{6}{|c|}{ Cases } \\
\hline & \multicolumn{2}{|c|}{ Valid } & \multicolumn{2}{|c|}{ Missing } & \multicolumn{2}{|c|}{ Total } \\
\hline & $\mathbf{N}$ & Percent & $\mathbf{N}$ & Percent & $\mathbf{N}$ & Percent \\
\hline Planning * Judgement & 143 & $100 \%$ & 0 & $0 \%$ & 143 & $100 \%$ \\
\hline Instructional Process * Judgement & 143 & $100 \%$ & 0 & $0 \%$ & 143 & $100 \%$ \\
\hline Assessment * Judgement & 143 & $100 \%$ & 0 & $0 \%$ & 143 & $100 \%$ \\
\hline Professionalism * Judgement & 143 & $100 \%$ & 0 & $0 \%$ & 143 & $100 \%$ \\
\hline International * Judgement & 143 & $100 \%$ & 0 & $0 \%$ & 143 & $100 \%$ \\
\hline Classroom * Judgement & 143 & $100 \%$ & 0 & $0 \%$ & 143 & $100 \%$ \\
\hline
\end{tabular}

Table 14 presents the summary of the cross tabulations for judgement and decision making and the identified factors for instructional competence. It can be incurred that there are 143 cases per cross tabulation and there is no missing cases for each cross tabulations being made.

\subsection{Planning * Judgement}

\section{Chi-Square Tests}

\begin{tabular}{|l|c|c|c|c|c|}
\hline & Value & Df & $\begin{array}{c}\text { Asymptotic Significance } \\
\text { (2-sided) }\end{array}$ & $\begin{array}{c}\text { Exact Sig. } \\
\text { (2-sided) }\end{array}$ & $\begin{array}{c}\text { Exact Sig. } \\
\text { (1-sided) }\end{array}$ \\
\hline Pearson Chi-Square & $.451^{\mathrm{a}}$ & 1 & .502 & & \\
\hline Continuity Correction & .000 & 1 & 1.000 & & \\
\hline Likelihood Ratio & .371 & 1 & .542 & & \\
\hline
\end{tabular}




\begin{tabular}{|l|c|c|c|c|c|}
\hline Fisher's Exact Test & & & .436 & .436 \\
\hline Linear-by-Linear Association & .447 & 1 & .504 & & \\
\hline N of Valid Cases & 143 & & & & \\
\hline a. 1 cells (25\%) have expected count less than 5. The minimum expected count is .54. \\
\hline \\
b. Computed only for a 2 x 2 table \\
\hline
\end{tabular}

\section{Findings:}

The relationship between Planning and Judgement and decision making was not significant: $\mathrm{X}^{2}(1$, $\mathrm{N}=143)=0.451, \mathrm{p}>0.05$.

\subsection{Instructional Process * Judgement}

Chi-Square Tests

\begin{tabular}{|l|c|c|c|c|c|}
\hline & Value & Df & $\begin{array}{c}\text { Asymptotic Significance } \\
\text { (2-sided) }\end{array}$ & $\begin{array}{c}\text { Exact Sig. } \\
\text { (2-sided) }\end{array}$ & $\begin{array}{c}\text { Exact Sig. } \\
\text { (1-sided) }\end{array}$ \\
\hline Pearson Chi-Square & $1.852^{\mathrm{a}}$ & 1 & .174 & & \\
\hline Continuity Correction & 1.067 & 1 & .302 & & \\
\hline Likelihood Ratio & 1.768 & 1 & .184 & & .200 \\
\hline Fisher's Exact Test & & & & .175 & .151 \\
\hline Linear-by-Linear Association & 1.839 & 1 & 143 & & \\
\hline N of Valid Cases \\
\hline
\end{tabular}

\section{Findings:}

The relationship between Instructional Process and Judgement and decision making was not significant: $\mathrm{X}^{2}(1, \mathrm{~N}=143)=1.85, \mathrm{p}>0.05$.

\subsection{Assessment * Judgement}

Chi-Square Tests

\begin{tabular}{|l|c|c|c|c|c|}
\hline & Value & Df & $\begin{array}{c}\text { Asymptotic Significance } \\
\text { (2-sided) }\end{array}$ & $\begin{array}{c}\text { Exact Sig. } \\
\text { (2-sided) }\end{array}$ & $\begin{array}{c}\text { Exact Sig. } \\
\text { (1-sided) }\end{array}$ \\
\hline Pearson Chi-Square & $.086^{\mathrm{a}}$ & 1 & .770 & & \\
\hline Continuity Correction & .000 & 1 & 1.000 & & \\
\hline Likelihood Ratio & .089 & 1 & .765 & 1.000 & .560 \\
\hline Fisher's Exact Test & & & & .770 & \\
\hline Linear-by-Linear Association & .085 & 1 & & & \\
\hline N of Valid Cases & 143 & & & & \\
\hline a. 1 cells (25\%) have expected count less than 5. The minimum expected count is 2.38. & \\
\hline b. Computed only for a 2 x 2 table
\end{tabular}

\section{Findings:}

The relationship between Assessment and Judgement and decision making was not significant: $\mathrm{X}^{2}$ $(1, \mathrm{~N}=143)=0.086, \mathrm{p}>0.05$. 


\subsection{Professionalism * Judgement}

Chi-Square Tests

\begin{tabular}{|l|c|c|c|c|c|}
\hline & Value & Df & $\begin{array}{c}\text { Asymptotic Significance } \\
\text { (2-sided) }\end{array}$ & $\begin{array}{c}\text { Exact Sig. } \\
\text { (2-sided) }\end{array}$ & $\begin{array}{c}\text { Exact Sig. } \\
\text { (1-sided) }\end{array}$ \\
\hline Pearson Chi-Square & $2.352^{\text {a }}$ & 1 & .125 & & \\
\hline Continuity Correction & 1.443 & 1 & .230 & .137 & .116 \\
\hline Likelihood Ratio & 2.214 & 1 & & .182 & \\
\hline Fisher's Exact Test & & & & & \\
\hline Linear-by-Linear Association & 2.336 & 1 & & & \\
\hline N of Valid Cases & 143 & & & & \\
\hline a. 1 cells (25\%) have expected count less than 5. The minimum expected count is 3.69. & \\
\hline b. Computed only for a 2 x 2 table
\end{tabular}

\section{Findings:}

The relationship between Professionalism and Judgement and decision making was not significant: $\mathrm{X}^{2}(1, \mathrm{~N}=143)=2.352, \mathrm{p}>0.05$.

\subsection{Interpersonal Relationship * Judgement}

\section{Chi-Square Tests}

\begin{tabular}{|l|c|c|c|c|c|}
\hline & Value & Df & $\begin{array}{c}\text { Asymptotic Significance } \\
\text { (2-sided) }\end{array}$ & $\begin{array}{c}\text { Exact Sig. } \\
\text { (2-sided) }\end{array}$ & $\begin{array}{c}\text { Exact Sig. } \\
\text { (1-sided) }\end{array}$ \\
\hline Pearson Chi-Square & $.430^{\mathrm{a}}$ & 1 & .512 & & \\
\hline Continuity Correction & .090 & 1 & .764 & .496 & .400 \\
\hline Likelihood Ratio & .463 & 1 & & .513 & \\
\hline Fisher's Exact Test & & & & & \\
\hline Linear-by-Linear Association & .427 & 1 & & & \\
\hline N of Valid Cases & 143 & & & & \\
\hline a. 1 cells (25\%) have expected count less than 5. The minimum expected count is 2.92. & \\
\hline b. Computed only for a 2 x 2 table
\end{tabular}

\section{Findings:}

The relationship between interpersonal relationship and Judgement and decision making was not significant: $\mathrm{X}^{2}(1, \mathrm{~N}=143)=0.430, \mathrm{p}>0.05$.

\subsection{Classroom * Judgement}

\section{Chi-Square Tests}

\begin{tabular}{|l|c|c|c|c|c|}
\hline & Value & Df & $\begin{array}{c}\text { Asymptotic Significance } \\
\text { (2-sided) }\end{array}$ & $\begin{array}{c}\text { Exact Sig. } \\
\text { (2-sided) }\end{array}$ & $\begin{array}{c}\text { Exact Sig. } \\
\text { (1-sided) }\end{array}$ \\
\hline Pearson Chi-Square & $.613^{\text {a }}$ & 1 & .434 & & \\
\hline Continuity Correction & .003 & 1 & .955 & & \\
\hline Likelihood Ratio & 1.150 & 1 & .284 & & \\
\hline Fisher's Exact Test & & & & 1.000 & .564 \\
\hline
\end{tabular}




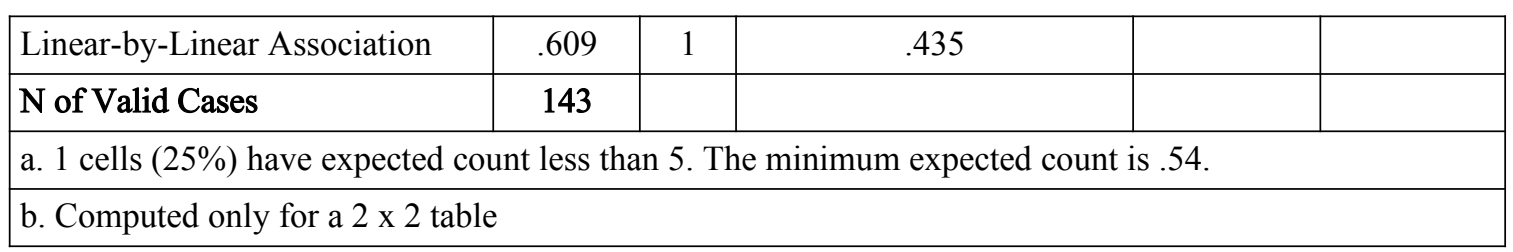

\section{Findings:}

The relationship between Classroom Management and Judgement and decision making was not significant: $\mathrm{X}^{2}(1, \mathrm{~N}=143)=0.613, \mathrm{p}>0.05$.

Table 15 - Case Processing Summary (Leadership * Instructional Competence)

\begin{tabular}{|l|c|c|c|c|c|c|}
\hline \multirow{2}{*}{} & \multicolumn{4}{|c|}{ Cases } \\
\cline { 2 - 7 } & \multicolumn{2}{|c|}{ Valid } & \multicolumn{2}{c|}{ Missing } & \multicolumn{3}{c|}{ Total } \\
\cline { 2 - 7 } & $\mathbf{N}$ & Percent & N & Percent & N & Percent \\
\hline Planning * Leadership & 143 & $100 \%$ & 0 & $0 \%$ & 143 & $100 \%$ \\
\hline Instructional Process * Leadership & 143 & $100 \%$ & 0 & $0 \%$ & 143 & $100 \%$ \\
\hline Assessment * Leadership & 143 & $100 \%$ & 0 & $0 \%$ & 143 & $100 \%$ \\
\hline Professionalism * Leadership & 143 & $100 \%$ & 0 & $0 \%$ & 143 & $100 \%$ \\
\hline International * Leadership & 143 & $100 \%$ & 0 & $0 \%$ & 143 & $100 \%$ \\
\hline Classroom * Leadership & 143 & $100 \%$ & 0 & $0 \%$ & 143 & $100 \%$ \\
\hline
\end{tabular}

Table 15 presents the summary of the cross tabulations Leadership and the identified factors for instructional competence. It can be incurred that there are 143 cases per cross tabulation and there is no missing cases for each cross tabulations being made.

\subsubsection{Planning * Leadership}

Chi-Square Tests

\begin{tabular}{|l|c|c|c|c|c|}
\hline & Value & Df & $\begin{array}{c}\text { Asymptotic Significance } \\
\text { (2-sided) }\end{array}$ & $\begin{array}{c}\text { Exact Sig. } \\
\text { (2-sided) }\end{array}$ & $\begin{array}{c}\text { Exact Sig. } \\
\text { (1-sided) }\end{array}$ \\
\hline Pearson Chi-Square & $121.677^{\mathrm{a}}$ & 1 & .000 & & \\
\hline Continuity Correction & 101.288 & 1 & .000 & .000 & .000 \\
\hline Likelihood Ratio & 44.056 & 1 & & .000 & \\
\hline Fisher's Exact Test & & & & & \\
\hline Linear-by-Linear Association & 120.826 & 1 & 143 & & \\
\hline N of Valid Cases
\end{tabular}

\subsubsection{Symmetric Measures}

\begin{tabular}{|l|l|c|c|}
\hline \multicolumn{2}{|c|}{} & Value & Approximate Significance \\
\hline \multirow{2}{*}{ Nominal by Nominal } & Phi & .922 & .000 \\
\cline { 2 - 4 } & Cramer's V & .922 & .000 \\
\hline N of Valid Cases & 143 & \\
\hline
\end{tabular}




\section{Findings:}

There is a significant relationship between planning and leadership $\mathrm{X}^{2}(1, \mathrm{~N}=143)=121.677, \mathrm{p}<$ $0.05 \mathrm{~V}_{\text {Cramer }}=0.922$. As indicated in table 15.1.2 the strength of association between the variables was near to a perfect association which implies that there is a very strong relationship between planning and leadership. Effective leadership skills entail effective planning techniques and strategies.

\subsection{Instructional Process * Leadership}

Chi-Square Tests

\begin{tabular}{|l|c|c|c|c|c|}
\hline & Value & Df & $\begin{array}{c}\text { Asymptotic Significance } \\
\text { (2-sided) }\end{array}$ & $\begin{array}{c}\text { Exact Sig. } \\
\text { (2-sided) }\end{array}$ & $\begin{array}{c}\text { Exact Sig. } \\
\text { (1-sided) }\end{array}$ \\
\hline Pearson Chi-Square & $.985^{\text {a }}$ & 1 & .321 & & \\
\hline Continuity Correction & .310 & 1 & .577 & & \\
\hline Likelihood Ratio & 1.107 & 1 & .293 & .422 & .302 \\
\hline Fisher's Exact Test & & & & & \\
\hline Linear-by-Linear Association & .978 & 1 & & & \\
\hline N of Valid Cases & 143 & & & & \\
\hline a. 2 cells (50\%) have expected count less than 5. The minimum expected count is 2.14. & \\
\hline b. Computed only for a 2 x 2 table
\end{tabular}

\section{Findings:}

The relationship between instructional process and Leadership was not significant $X^{2}(1, N=143)=$ $0.985, \mathrm{p}>0.05$.

\subsection{Assessment * Leadership}

\section{Chi-Square Tests}

\begin{tabular}{|l|c|c|c|c|c|}
\hline & Value & Df & $\begin{array}{c}\text { Asymptotic Significance } \\
\text { (2-sided) }\end{array}$ & $\begin{array}{c}\text { Exact Sig. } \\
\text { (2-sided) }\end{array}$ & $\begin{array}{c}\text { Exact Sig. } \\
\text { (1-sided) }\end{array}$ \\
\hline Pearson Chi-Square & $.093^{\mathrm{a}}$ & 1 & .761 & & \\
\hline Continuity Correction & .000 & 1 & 1.000 & & \\
\hline Likelihood Ratio & .098 & 1 & .754 & & \\
\hline Fisher's Exact Test & & & & 1.000 & .613 \\
\hline Linear-by-Linear Association & .092 & 1 & .762 & & \\
\hline N of Valid Cases & 143 & & & & \\
\hline a. 2 cells (50\%) have expected count less than 5. The minimum expected count is 1.30. \\
\hline b. Computed only for a 2 $\times 2$ table
\end{tabular}

\section{Findings:}

The relationship between assessment and Leadership was not significant: $X^{2}(1, N=143)=0.93, p$ $>0.05$. 


\subsection{Professionalism * Leadership}

Chi-Square Tests

\begin{tabular}{|c|c|c|c|c|c|}
\hline & Value & Df & $\begin{array}{c}\text { Asymptotic Significance } \\
\text { (2-sided) }\end{array}$ & $\begin{array}{l}\text { Exact Sig. } \\
\text { (2-sided) }\end{array}$ & $\begin{array}{l}\text { Exact Sig. } \\
\text { (1-sided) }\end{array}$ \\
\hline Pearson Chi-Square & $.802^{\mathrm{a}}$ & 1 & .370 & & \\
\hline Continuity Correction & .206 & 1 & .650 & & \\
\hline Likelihood Ratio & .900 & 1 & .343 & & \\
\hline Fisher's Exact Test & & & & .664 & .342 \\
\hline Linear-by-Linear Association & .797 & 1 & .372 & & \\
\hline $\mathrm{N}$ of Valid Cases & 143 & & & & \\
\hline \multicolumn{6}{|c|}{ a. 2 cells $(50 \%)$ have expected count less than 5 . The minimum expected count is 2.01 . } \\
\hline \multicolumn{6}{|l|}{ b. Computed only for a $2 \times 2$ table } \\
\hline
\end{tabular}

\section{Findings:}

The relationship between Professionalism and Leadership was not significant: $X^{2}(1, N=143)=$ $0.802, \mathrm{p}>0.05$.

\subsection{Interpersonal Relationship * Leadership}

\section{Chi-Square Tests}

\begin{tabular}{|l|c|c|c|c|c|}
\hline & Value & Df & $\begin{array}{c}\text { Asymptotic Significance } \\
\text { (2-sided) }\end{array}$ & $\begin{array}{c}\text { Exact Sig. } \\
\text { (2-sided) }\end{array}$ & $\begin{array}{c}\text { Exact Sig. } \\
\text { (1-sided) }\end{array}$ \\
\hline Pearson Chi-Square & $.315^{\mathrm{a}}$ & 1 & .575 & & \\
\hline Continuity Correction & .008 & 1 & .929 & & \\
\hline Likelihood Ratio & .346 & 1 & .557 & & \\
\hline Fisher's Exact Test & & & & 1.000 & .494 \\
\hline Linear-by-Linear Association & .313 & 1 & .576 & & \\
\hline N of Valid Cases & 143 & & & & \\
\hline a. 2 cells (50\%) have expected count less than 5. The minimum expected count is 1.59. \\
\hline b. Computed only for a 2 2 table \\
\hline
\end{tabular}

\section{Findings:}

The relationship between interpersonal relationship and Leadership was not significant: $X^{2}(1, N=$ $143)=0.315, \mathrm{p}>0.05$.

\subsubsection{Classroom * Leadership}

\section{Chi-Square Tests}

\begin{tabular}{|l|c|c|c|c|c|}
\hline & Value & Df & $\begin{array}{c}\text { Asymptotic Significance } \\
\text { (2-sided) }\end{array}$ & $\begin{array}{c}\text { Exact Sig. } \\
\text { (2-sided) }\end{array}$ & $\begin{array}{c}\text { Exact Sig. } \\
\text { (1-sided) }\end{array}$ \\
\hline Pearson Chi-Square & $121.677^{\mathrm{a}}$ & 1 & .000 & & \\
\hline Continuity Correction & 101.288 & 1 & .000 & & \\
\hline Likelihood Ratio & 44.056 & 1 & .000 & & \\
\hline Fisher's Exact Test & & & & .000 & .000 \\
\hline Linear-by-Linear Association & 120.826 & 1 & .000 & & \\
\hline
\end{tabular}




\begin{tabular}{|l|l|l|l|}
\hline N of Valid Cases & 143 & & \\
\hline a. 1 cells $(25 \%)$ have expected count less than 5 . The minimum expected count is .29. \\
\hline b. Computed only for a $2 \times 2$ table \\
\hline
\end{tabular}

\subsubsection{Symmetric Measures}

\begin{tabular}{|l|l|c|c|}
\hline \multicolumn{2}{|c|}{} & Value & Approximate Significance \\
\hline \multirow{2}{*}{ Nominal by Nominal } & Phi & .922 & .000 \\
\cline { 2 - 4 } & Cramer's V & .922 & .000 \\
\hline N of Valid Cases & 143 & \\
\hline
\end{tabular}

\section{Findings:}

There is a significant relationship between Classroom Management and leadership $X^{2}(1, N=143)$ $=121.677, \mathrm{p}<0.05 \mathrm{~V}_{\text {Cramer }}=0.922$. As indicated in table 15.6.2 the strength of association between the variables was near to a perfect association which implies that there is a very strong relationship between classroom management and leadership.

Table 16 - Case Processing Summary (Teamwork * Instructional Competence)

\begin{tabular}{|l|c|c|c|c|c|c|}
\hline \multirow{2}{*}{} & \multicolumn{4}{|c|}{ Cases } \\
\cline { 2 - 7 } & \multicolumn{2}{|c|}{ Valid } & \multicolumn{2}{c|}{ Missing } & \multicolumn{2}{c|}{ Total } \\
\cline { 2 - 8 } & N & Percent & N & Percent & N & Percent \\
\hline Planning * Teamwork & 143 & $100 \%$ & 0 & $0 \%$ & 143 & $100 \%$ \\
\hline Instructional Process * Teamwork & 143 & $100 \%$ & 0 & $0 \%$ & 143 & $100 \%$ \\
\hline Assessment * Teamwork & 143 & $100 \%$ & 0 & $0 \%$ & 143 & $100 \%$ \\
\hline Professionalism * Teamwork & 143 & $100 \%$ & 0 & $0 \%$ & 143 & $100 \%$ \\
\hline International * Teamwork & 143 & $100 \%$ & 0 & $0 \%$ & 143 & $100 \%$ \\
\hline Classroom * Teamwork & 143 & $100 \%$ & 0 & $0 \%$ & 143 & $100 \%$ \\
\hline
\end{tabular}

Table 16 presents the summary of the cross tabulations Teamwork and the identified factors for instructional competence. It can be incurred that there are 143 cases per cross tabulation and there is no missing cases for each cross tabulations being made.

\subsection{Planning * Teamwork}

Chi-Square Tests

\begin{tabular}{|c|c|c|c|c|c|}
\hline & Value & Df & $\begin{array}{c}\text { Asymptotic Significance } \\
\text { (2-sided) }\end{array}$ & $\begin{array}{l}\text { Exact Sig. } \\
\text { (2-sided) }\end{array}$ & $\begin{array}{l}\text { Exact Sig. } \\
\text { (1-sided) }\end{array}$ \\
\hline Pearson Chi-Square & $.206^{\mathrm{a}}$ & 1 & .650 & & \\
\hline Continuity Correction & .000 & 1 & 1.000 & & \\
\hline Likelihood Ratio & .193 & 1 & .660 & & \\
\hline Fisher's Exact Test & & & & .645 & .472 \\
\hline Linear-by-Linear Association & .205 & 1 & .651 & & \\
\hline $\mathrm{N}$ of Valid Cases & 143 & & & & \\
\hline \multicolumn{6}{|c|}{ a. 1 cells $(25 \%)$ have expected count less than 5 . The minimum expected count is 1.52 . } \\
\hline
\end{tabular}




\section{Findings:}

The relationship between planning and teamwork was not significant: $X^{2}(1, N=143)=0.206, p>$ 0.05 .

\subsection{Instructional Process * Teamwork}

Chi-Square Tests

\begin{tabular}{|l|c|c|c|c|c|}
\hline & Value & Df & $\begin{array}{c}\text { Asymptotic Significance } \\
\text { (2-sided) }\end{array}$ & $\begin{array}{c}\text { Exact Sig. } \\
\text { (2-sided) }\end{array}$ & $\begin{array}{c}\text { Exact Sig. } \\
\text { (1-sided) }\end{array}$ \\
\hline Pearson Chi-Square & $.200^{\mathrm{a}}$ & 1 & .655 & & \\
\hline Continuity Correction & .055 & 1 & .814 & & \\
\hline Likelihood Ratio & .202 & 1 & .653 & & .832 \\
\hline Fisher's Exact Test & & & & .656 & .411 \\
\hline Linear-by-Linear Association & .199 & 1 & & & \\
\hline N of Valid Cases & 143 & & & \\
\hline a. 0 cells (0\%) have expected count less than 5. The minimum expected count is 11.06. \\
\hline b. Computed only for a 2 2 table \\
\hline
\end{tabular}

\section{Findings:}

The relationship between instructional process and teamwork was not significant $\{X\}^{\wedge}\{2\}$ left $(1$, $\mathrm{N}=143)=0.2, \mathrm{p}>0.05$.

\subsubsection{Assessment * Teamwork}

\section{Chi-Square Tests}

\begin{tabular}{|l|c|c|c|c|c|}
\hline & Value & Df & $\begin{array}{c}\text { Asymptotic Significance } \\
\text { (2-sided) }\end{array}$ & $\begin{array}{c}\text { Exact Sig. } \\
\text { (2-sided) }\end{array}$ & $\begin{array}{c}\text { Exact Sig. } \\
\text { (1-sided) }\end{array}$ \\
\hline Pearson Chi-Square & $6.762^{\mathrm{a}}$ & 1 & .009 & & \\
\hline Continuity Correction & 5.542 & 1 & .019 & & \\
\hline Likelihood Ratio & 6.150 & 1 & .013 & & .014 \\
\hline Fisher's Exact Test & & & & .010 & .012 \\
\hline Linear-by-Linear Association & 6.715 & 1 & \multicolumn{7}{|l|}{} \\
\hline N of Valid Cases & 143 & & & \\
\hline a. 0 cells (0\%) have expected count less than 5. The minimum expected count is 6.72. \\
\hline b. Computed only for a 2 2 table \\
\hline
\end{tabular}

\subsubsection{Symmetric Measures}

\begin{tabular}{|l|l|c|c|}
\hline \multicolumn{2}{|c|}{} & Value & Approximate Significance \\
\hline \multirow{2}{*}{ Nominal by Nominal } & Phi & .217 & .009 \\
\cline { 2 - 4 } & Cramer's V & .217 & .009 \\
\hline N of Valid Cases & 143 & \\
\hline
\end{tabular}




\section{Findings:}

There is a significant relationship between Assessment and Teamwork: $\mathrm{X}^{2}(1, \mathrm{~N}=143)=6.762, \mathrm{p}<$ $0.05 \mathrm{~V}_{\text {Cramer }}=0.217$. As indicated in table 16.3.2 the strength of association between the variables can be classified as weak. The statistical result suggests that the two variables may reveal relationship but with respect to the strength of the association, it can be concluded that there is a weak relationship between the variables.

\subsection{Professionalism * Teamwork}

\section{Chi-Square Tests}

\begin{tabular}{|c|c|c|c|c|c|}
\hline & Value & Df & $\begin{array}{c}\text { Asymptotic Significance } \\
\text { (2-sided) }\end{array}$ & $\begin{array}{l}\text { Exact Sig. } \\
\text { (2-sided) }\end{array}$ & $\begin{array}{l}\text { Exact Sig. } \\
\text { (1-sided) }\end{array}$ \\
\hline Pearson Chi-Square & $.365^{\mathrm{a}}$ & 1 & .546 & & \\
\hline Continuity Correction & .151 & 1 & .697 & & \\
\hline Likelihood Ratio & .372 & 1 & .542 & & \\
\hline Fisher's Exact Test & & & & .669 & .353 \\
\hline Linear-by-Linear Association & .362 & 1 & .547 & & \\
\hline $\mathrm{N}$ of Valid Cases & 143 & & & & \\
\hline
\end{tabular}

\section{Findings:}

The relationship between professionalism and teamwork was not significant: $X^{2}(1, N=143)=$ $0.365, \mathrm{p}>0.05$.

\subsection{Interpersonal Relationship * Teamwork}

\section{Chi-Square Tests}

\begin{tabular}{|c|c|c|c|c|c|}
\hline & Value & $\mathrm{Df}$ & $\begin{array}{c}\text { Asymptotic Significance } \\
\text { (2-sided) }\end{array}$ & $\begin{array}{l}\text { Exact Sig. } \\
\text { (2-sided) }\end{array}$ & $\begin{array}{l}\text { Exact Sig. } \\
\text { (1-sided) }\end{array}$ \\
\hline Pearson Chi-Square & $1.057^{\mathrm{a}}$ & 1 & .304 & & \\
\hline Continuity Correction & .637 & 1 & .425 & & \\
\hline Likelihood Ratio & 1.111 & 1 & .292 & & \\
\hline Fisher's Exact Test & & & & .364 & .215 \\
\hline Linear-by-Linear Association & 1.050 & 1 & .306 & & \\
\hline $\mathrm{N}$ of Valid Cases & 143 & & & & \\
\hline \multicolumn{6}{|c|}{ a. 0 cells $(0 \%)$ have expected count less than 5 . The minimum expected count is 8.24 . } \\
\hline \multicolumn{6}{|c|}{ b. Computed only for a $2 \times 2$ table } \\
\hline
\end{tabular}

\section{Findings:}

The relationship between interpersonal relationship and teamwork was not significant: $X^{2}(1, N=$ $143)=1.057, \mathrm{p}>0.05$. 


\subsection{Classroom * Teamwork}

Chi-Square Tests

\begin{tabular}{|c|c|c|c|c|c|}
\hline & Value & Df & $\begin{array}{c}\text { Asymptotic Significance } \\
\text { (2-sided) }\end{array}$ & $\begin{array}{l}\text { Exact Sig. } \\
\text { (2-sided) }\end{array}$ & $\begin{array}{l}\text { Exact Sig. } \\
\text { (1-sided) }\end{array}$ \\
\hline Pearson Chi-Square & $.206^{\mathrm{a}}$ & 1 & .650 & & \\
\hline Continuity Correction & .000 & 1 & 1.000 & & \\
\hline Likelihood Ratio & .193 & 1 & .660 & & \\
\hline Fisher's Exact Test & & & & .645 & .472 \\
\hline Linear-by-Linear Association & .205 & 1 & .651 & & \\
\hline $\mathrm{N}$ of Valid Cases & 143 & & & & \\
\hline \multicolumn{6}{|c|}{ a. 1 cells $(25 \%)$ have expected count less than 5 . The minimum expected count is 1.52 . } \\
\hline \multicolumn{6}{|c|}{ b. Computed only for a $2 \times 2$ table } \\
\hline
\end{tabular}

Findings:

The relationship between classroom management and teamwork was not significant: $X^{2}(1, N=$ $143)=0.206, p>0.05$.

Table 17 - Case Processing Summary (Creativity * Instructional Competence)

\begin{tabular}{|l|c|c|c|c|c|c|}
\hline \multirow{2}{*}{} & \multicolumn{6}{|c|}{ Cases } \\
\cline { 2 - 7 } & \multicolumn{2}{|c|}{ Valid } & \multicolumn{2}{c|}{ Missing } & \multicolumn{2}{c|}{ Total } \\
\cline { 2 - 7 } & $\mathbf{N}$ & Percent & $\mathbf{N}$ & Percent & $\mathbf{N}$ & Percent \\
\hline Planning * Creativity & 143 & $100 \%$ & 0 & $0 \%$ & 143 & $100 \%$ \\
\hline Instructional Process * Creativity & 143 & $100 \%$ & 0 & $0 \%$ & 143 & $100 \%$ \\
\hline Assessment * Creativity & 143 & $100 \%$ & 0 & $0 \%$ & 143 & $100 \%$ \\
\hline Professionalism * Creativity & 143 & $100 \%$ & 0 & $0 \%$ & 143 & $100 \%$ \\
\hline International * Creativity & 143 & $100 \%$ & 0 & $0 \%$ & 143 & $100 \%$ \\
\hline Classroom * Creativity & 143 & $100 \%$ & 0 & $0 \%$ & 143 & $100 \%$ \\
\hline
\end{tabular}

Table 17 presents the summary of the cross tabulations for creativity and the identified factors for instructional competence. It can be incurred that there are 143 cases per cross tabulation and there is no missing cases for each cross tabulations being made.

\subsection{Planning * Creativity}

Chi-Square Tests

\begin{tabular}{|l|c|c|c|c|c|}
\hline & Value & Df & $\begin{array}{c}\text { Asymptotic Significance } \\
\text { (2-sided) }\end{array}$ & $\begin{array}{c}\text { Exact Sig. } \\
\text { (2-sided) }\end{array}$ & $\begin{array}{c}\text { Exact Sig. } \\
\text { (1-sided) }\end{array}$ \\
\hline Pearson Chi-Square & $.436^{\mathrm{a}}$ & 1 & .509 & & \\
\hline Continuity Correction & .000 & 1 & 1.000 & & \\
\hline Likelihood Ratio & .827 & 1 & .363 & 1.000 & .662 \\
\hline Fisher's Exact Test & & & & & \\
\hline Linear-by-Linear Association & .433 & 1 & .510 & & \\
\hline N of Valid Cases & 143 & & & & \\
\hline a. 1 cells (25\%) have expected count less than 5. The minimum expected count is .39. & \\
\hline
\end{tabular}




\section{Findings:}

The relationship between planning and Creativity was not significant: $X^{2}(1, N=143)=0.436, p>$ 0.05 .

\subsection{Instructional Process * Creativity}

Chi-Square Tests

\begin{tabular}{|c|c|c|c|c|c|}
\hline & Value & Df & $\begin{array}{c}\text { Asymptotic Significance } \\
\text { (2-sided) }\end{array}$ & $\begin{array}{l}\text { Exact Sig. } \\
\text { (2-sided) }\end{array}$ & $\begin{array}{l}\text { Exact Sig. } \\
\text { (1-sided) }\end{array}$ \\
\hline Pearson Chi-Square & $1.982^{\mathrm{a}}$ & 1 & .159 & & \\
\hline Continuity Correction & 1.057 & 1 & .304 & & \\
\hline Likelihood Ratio & 2.319 & 1 & .128 & & \\
\hline Fisher's Exact Test & & & & .259 & .152 \\
\hline Linear-by-Linear Association & 1.968 & 1 & .161 & & \\
\hline $\mathrm{N}$ of Valid Cases & 143 & & & & \\
\hline \multicolumn{6}{|c|}{ a. 1 cells $(25 \%)$ have expected count less than 5 . The minimum expected count is 2.85 . } \\
\hline b. Computed only for a $2 \times 2 \mathrm{t}$ & & & & & \\
\hline
\end{tabular}

\section{Findings:}

The relationship between Instructional Competence and Creativity was not significant: $X^{2}(1, N=$ $143)=1.982, \mathrm{p}>0.05$.

\subsection{Assessment * Creativity}

Chi-Square Tests

\begin{tabular}{|l|c|c|c|c|c|}
\hline & Value & Df & $\begin{array}{c}\text { Asymptotic Significance } \\
\text { (2-sided) }\end{array}$ & $\begin{array}{c}\text { Exact Sig. } \\
\text { (2-sided) }\end{array}$ & $\begin{array}{c}\text { Exact Sig. } \\
\text { (1-sided) }\end{array}$ \\
\hline Pearson Chi-Square & $.420^{\mathrm{a}}$ & 1 & .517 & & \\
\hline Continuity Correction & .043 & 1 & .836 & & \\
\hline Likelihood Ratio & .474 & 1 & .491 & 1.000 & .450 \\
\hline Fisher's Exact Test & & & & & \\
\hline Linear-by-Linear Association & .418 & 1 & .518 & & \\
\hline N of Valid Cases & 143 & & & & \\
\hline a. 1 cells (25\%) have expected count less than 5. The minimum expected count is 1.73. & \\
\hline b. Computed only for a 2 x 2 table
\end{tabular}

\section{Findings:}

The relationship between Assessment and Creativity was not significant: $X^{2}(1, N=143)=0.420, p$ $>0.05$. 


\subsection{Professionalism * Creativity}

Chi-Square Tests

\begin{tabular}{|c|c|c|c|c|c|}
\hline & Value & Df & $\begin{array}{c}\text { Asymptotic Significance } \\
\text { (2-sided) }\end{array}$ & $\begin{array}{l}\text { Exact Sig. } \\
\text { (2-sided) }\end{array}$ & $\begin{array}{l}\text { Exact Sig. } \\
\text { (1-sided) }\end{array}$ \\
\hline Pearson Chi-Square & $1.026^{\mathrm{a}}$ & 1 & .311 & & \\
\hline Continuity Correction & .394 & 1 & .530 & & \\
\hline Likelihood Ratio & .972 & 1 & .324 & & \\
\hline Fisher's Exact Test & & & & .442 & .259 \\
\hline Linear-by-Linear Association & 1.019 & 1 & .313 & & \\
\hline $\mathrm{N}$ of Valid Cases & 143 & & & & \\
\hline \multicolumn{6}{|c|}{ a. 1 cells $(25 \%)$ have expected count less than 5 . The minimum expected count is 2.69 . } \\
\hline \multicolumn{6}{|c|}{ b. Computed only for a $2 \times 2$ table } \\
\hline
\end{tabular}

\section{Findings:}

The relationship between Professionalism and Creativity was not significant: $X^{2}(1, N=143)=$ $1.026, \mathrm{p}>0.05$.

\subsection{Interpersonal Relationship * Creativity}

\section{Chi-Square Tests}

\begin{tabular}{|c|c|c|c|c|c|}
\hline & Value & Df & $\begin{array}{c}\text { Asymptotic Significance } \\
\text { (2-sided) }\end{array}$ & $\begin{array}{l}\text { Exact Sig. } \\
\text { (2-sided) }\end{array}$ & $\begin{array}{l}\text { Exact Sig. } \\
\text { (1-sided) }\end{array}$ \\
\hline Pearson Chi-Square & $.519^{\mathrm{a}}$ & 1 & .471 & & \\
\hline Continuity Correction & .095 & 1 & .758 & & \\
\hline Likelihood Ratio & .485 & 1 & .486 & & \\
\hline Fisher's Exact Test & & & & .438 & .360 \\
\hline Linear-by-Linear Association & .515 & 1 & .473 & & \\
\hline $\mathrm{N}$ of Valid Cases & 143 & & & & \\
\hline \multicolumn{6}{|c|}{ a. 1 cells $(25 \%)$ have expected count less than 5 . The minimum expected count is 2.13 . } \\
\hline b. Computed only for a $2 \times 2$ ta & & & & & \\
\hline
\end{tabular}

\section{Findings:}

The relationship between Interpersonal Relationship and Creativity was not significant: $X^{2}(1, N=$ $143)=0.519, \mathrm{p}>0.05$.

\subsection{Classroom * Creativity}

\section{Chi-Square Tests}

\begin{tabular}{|l|c|c|c|c|c|}
\hline & Value & Df & $\begin{array}{c}\text { Asymptotic Significance } \\
\text { (2-sided) }\end{array}$ & $\begin{array}{c}\text { Exact Sig. } \\
\text { (2-sided) }\end{array}$ & $\begin{array}{c}\text { Exact Sig. } \\
\text { (1-sided) }\end{array}$ \\
\hline Pearson Chi-Square & $.436^{\mathrm{a}}$ & 1 & .509 & & \\
\hline Continuity Correction & .000 & 1 & 1.000 & & \\
\hline Likelihood Ratio & .827 & 1 & .363 & & \\
\hline Fisher's Exact Test & & & & 1.000 & .662 \\
\hline Linear-by-Linear Association & .433 & 1 & .510 & & \\
\hline
\end{tabular}




\begin{tabular}{|l|r|l|l|l|}
\hline $\mathbf{N}$ of Valid Cases & 143 & & & \\
\hline a. 1 cells $(25 \%)$ have expected count less than 5 . The minimum expected count is .39. \\
\hline b. Computed only for a $2 \times 2$ table \\
\hline
\end{tabular}

\section{Findings:}

The relationship between Classroom Management and Creativity was not significant: $X^{2}(1, N=$ $143)=0.436, p>0.05$.

\section{Chapter 4 - Summary of Findings, Conclusion and Recommendations}

This chapter presents a summary of findings, conclusions, and recommendations based on the findings of the study.

\section{Summary of Findings}

This study "Correlational Study of Organizational Key Behavior and Teachers' Competencies in Sapangdalaga District Division of Misamis Occidental SY 2020-2021", sought to analyze the association that occurs between Teachers competence and organizational Key behavior. As revealed in the statistical calculations, the following descriptive and inferential results were found out:

1. Indicators in the Teachers organizational key behavior which were Communication, Judgement and decision Making, Leadership, Teamwork was perceived as high.

2. There is only one indicator for the teachers organization key behavior in Creativity which was "Identifies and visualizes options and formulates innovative approaches" was perceived as very high $(\mathrm{M}=4.25, \mathrm{SD}=0.97)$.

3. The Teachers' level of instructional competence constituted a verbal interpretation of "Good" for all its components and indicators.

4. It was found out that there exists a significant relationship between the following:

4.1 Instructional Process and Communication: $\mathrm{X}^{2}(1, \mathrm{~N}=143)=37.27, \mathrm{p}<0.05 \mathrm{~V}_{\text {Cramer }}=0.51$

4.2 Professionalism and Communication: $\mathrm{X}^{2}(1, \mathrm{~N}=143)=5.324, \mathrm{p}<0.05 \mathrm{~V}_{\text {Cramer }}=0.19$

4.3 Planning and Leadership: $\mathrm{X}^{2}(1, \mathrm{~N}=143)=121.677, \mathrm{p}<0.05 \mathrm{~V}_{\text {Cramer }}=0.922$

4.4 Assessment and Teamwork: $\mathrm{X}^{2}(1, \mathrm{~N}=143)=6.762, \mathrm{p}<0.05 \mathrm{~V}_{\text {Cramer }}=0.217$

\section{Conclusion}

In the light of the findings of the study, the following conclusions can be drawn;

1. The organizational behavior and instructional competence of the teachers can be marginally regarded as high and good respectively.

2. There was an association between instructional process and communication which was characterized as a "near perfect strength of association" which suggest the strong relationship between the two variables. One's communication skills will greatly affect teachers' competence in the instructional process.

3. Professionalism and communication skills constituted a relationship however the strength of association can be characterized as weak. We can conclude that one's communication skills affects professionalism but partly, this association is not substantially strong.

4. Planning and leadership was characterized as significantly related with a very strong association. Hence, leadership skills are a salient factor towards effective planning. 
5. Assessment and Teamwork was revealed as significantly associated but the strength of association was verbally interpreted as weak. Thus, we can conclude that each variable mentioned affects one another but with respect to their association, it can be regarded as weak.

\section{Recommendations}

It is imperative to study organizational behavior because it explains why teachers behave in school organizations. The importance of organization has tremendous necessities. In this study, organizational behavior helps us teachers (human beings) understand their complex nature in the organization by determining the interactions of their essential organization behavior and its interaction effects on their instructional competence.

First, school administrators should benefit from a better understanding and more in-depth insight into the relevance of organizational behavior in instruction effectiveness concerning teacher's competence. Failure to do this will undoubtedly result in the lowering of school organizational effectiveness and the commitment effect of the inability to meet both teachers' personal and school organizational goals.

Secondly, school administrators may adopt general approaches to take advantage of the importance of organizational behaviors in school organization as following:

1. Organizational Behavior helps in understanding school organization and teachers in a better way in which supports the effective organization and improve teacher's performance;

2. Organizational Behavior helps in motivating teachers;

3. Provide opportunities for performance and self-actualization of teachers' potentials, allowing them adequate freedom for ingenuity and creativity in achieving goals and;

4. Career advancement opportunities.

Organizational behavior helps determine the factor causing the action and helps school administrators and teachers apply different strategies to control critical factors that affect teachers' competence.

Further studies on this subject may include organizational behavior within groups or organizations and model behavior through analysis of the organizations' positive impact.

Influencing teacher's behavior is another important aspect of studying school organizational behavior. It helps the school administrators assess teachers' reactions before making any changes in policies or schemes.

\section{Bibliography}

\section{A. Books}

1. Goleman, Daniel. (1995). Emotional Intelligence. New York: Bantam

2. Mintzberg, Henry. (1989). Mintzberg on Management. New York: Free Press

3. Schermerhorn, John, Jr., James Hunt, Richard Osborn. (2004). Core Concepts of Organizational Behavior. New York: John Wiley \& Sons

4. Shields, Patricia, Rangarajan, N. (2013). A Playbook for Research Methods: Integrating Conceptual Frameworks and Project Management. Stillwater, OK: New Forums Press 


\section{B. Periodicals}

1. Babu, A., Kumari, M. (2013). Organizational climate as a predictor of teacher effectiveness. European Academic Research, Vol. 5., pp. 553-568

2. Batlolona, John. (2018). Organizational Climate of the School and Teacher Performance

3. Improvement in the 21st Century. International Journal of Science and Research (IJSR). 7. pp. 119-126

4. Kahn, Jeremy. (October 26, 1998). What Makes a Company Great? Fortune. p. 218

5. Kapur, Radhika. (2018). Study of Organizational Behavior in Education

6. Katz, Robert L. (September/October 1974). Skills of an Effective Administrator. Harvard Business Review. p. 52

7. Kunter, M., Klusmann, U., Baumert, J., Richter, D., Voss, T., Hachfeld, A. (2013). Professional competence of teachers: Effects on instructional quality and student development. Journal of Educational Psychology, 105 (3). pp. 805-820

8. MacNeil, A. J., Prater, D. L., \& Busch, S. (2009). The effects of school culture and climate on student achievement. International Journal of Leadership in Education, 12 (1). pp. 73-84

9. Nussbaum, Jon F. (1992). Effective Teacher Behaviors. Communication Education. 41 (2). pp. 167-180

10. Rashid, Muhammad, Zaman, Saeed. (2018). Effects of Teacher's Behavior on Academic Performance of Students. In proceedings

11. Shields, Patricia, and Hassan Tajalli. (2006). Intermediate Theory: The Missing Link in Successful Student Scholarship. Journal of Public Affairs Education. Vol. 12, No. 3., pp. 313334

12. Teven Jason J. (2007). Teacher Caring and Classroom Behavior: Relationships with Student

13. Affect and Perceptions of Teacher Competence and Trustworthiness. Communication Quarterly. 55 (4).pp. 433-450

14. Usop Annierah, Kadtong Maeda, Amir Datu, Usop Sajid. (2013). The Significant

15. Relationship between Work Performance and Job Satisfaction in the Philippines. International Journal of Human Resource Management and Research (IJHRMR). 3. pp. 9-16

16. Yusof, Najeemah. (2012). School Climate and Teachers' Commitment: A Case Study of Malaysia. International Journal of Economics Business and Management Studies, 1 (2). pp. 6575. https://ssrn.com/abstract $=2151470$

\section{Unpublished Materials}

1. Blazar, David. (2016). Teacher and Teaching Effects on Students' Academic Performance, Attitudes, and Behaviors. Doctoral Dissertation, Harvard Graduate School of Education

2. Sabado, Norberta Pahamutang. (2014). The Influence of Leadership Behavior of School Heads to the Performance of Public and Private High School Teachers in Kidapawan City Division. Doctoral Dissertation. Graduate School, University of Southern Mindanao. pp.160

3. Villaluz, Macrina, K. (2018). Organizational Climate in Public Schools of Sibulan: A Basis for School Climate Creativity and Innovation. Doctoral Dissertation. Graduate School, Foundation University 


\section{Online Document}

1. Republic Act 9155. (2001, August 11). Governance of Basic Education Act of 2001. Retrieved from Official Gazette: http://www.officialgazette.gov.ph/2001/08/11/republic-act-no-9155/

2. Adonis Fulgar Cerbito. (2020). Comparative Analysis of Mathematics Proficiency and Attitudes toward Mathematics of Senior High School Student; International Journal of Scientific and Research Publications (IJSRP) 10 (5), DOI: 10.29322/IJSRP.10.05.2020.p10125

3. https://www.managementstudyguide.com/organizational-leadership.htm

4. Hedge, T. (2000). Teaching and learning in the language classroom: A guide to current ideas about the theory and practice of English language teaching. Oxford: Oxford University Press

5. Black, P., Wiliam, D. (2006). Inside the black box: Raising standards through classroom assessment. Granada Learning

\section{A Correlational Study of Organizational Key Behavior and Teachers' Competencies in Sapangdalaga District Division of Misamis Occidental Sy 2020-2021}

\section{Part 1}

Directions: Below are statements concerning organizational behaviors that a classroom teacher is expected to perform. Survey participants were asked to choose a number between 1 to 5 for each topic according to the following legend according to how much they are agree to it.

\section{Legend:}

$$
\begin{aligned}
& 5=\text { Very High } \\
& 4=\text { High } \\
& 3=\text { Average } \\
& 2=\text { Low } \\
& 1=\text { Very Low }
\end{aligned}
$$

\section{Organizational Behavior}

\section{A. Communication}

1. Recognize and understand the perspective of other people.

2. Receive feedback and learn from it.

3. Present information to the audience.

4. Great written and oral skills.

5. Initiate dialogue and involve people in the communication process.

6. Ability to bring value to people y presenting them certain information.

7. Establishment of strong connections with people through communication.

8. Presents an open and accepting persona that allows the most to reluctant person to express his/her views.

9. Encourages an open exchange of ideas and different points of view; tells the truth even when it is unwelcome.

10. Demonstrates a keen ability to recognize when others are having difficulty understanding his messages; and adapts style appropriately. 


\section{B. Judgment And Decision Making Ability}

1. Demonstrate an ability to make effective decisions within limited time.

2. Develops highly creative and effective solutions despite.

3. The teacher demonstrates maturity in dealing with students.

4. The teacher seeks opportunities for his professional development.

5. The teacher demonstrates sound judgement in decision-making.

6. The teacher contributes to the life of the school including co-curricular activities.

7. The teacher demonstrates leadership skills in the performance of duties.

8. The teachers adhere to the code of ethics.

\section{Leadership Skills}

1. Encourages a sense of mutual accountability in class settings that motivates students to do his best for each other and exceed goals.

2. Identifies the most important priorities for the class and focuses attention effectively.

3. Provides direction to less experienced teacher on how to monitor the class without interfering student progress.

4. Demonstrates an ability to identify underlying performance issues among the class and delivery highly insightful feedback.

5. Effective gives constructive feedback even when the message is extremely difficult to deliver.

6. Helps the students develop their ability to anticipate problems by leveraging their past experiences so that they can work independently.

7. Positive influence on other teachers and students and their motivation.

8. Ability to serve as an example and act correspondingly.

9. Ability to take responsibility and accountability.

10. Ability to encourage, coach, teach and assist other people.

\section{Teamwork and Cooperation}

1. Frequently uses opportunities to work with others as a teaching tool to impart organizational knowledge and help others succeed.

2. Actively seeks to eliminate "cliques" and assists in problem solving so that all teachers and students can be included in work processes.

3. Builds loyalty among other teachers in the organization.

4. Provides guidance to others as they work through conflicts and disagreements so they can become better "team players".

5. Facilitates communication between people experiencing conflict who have previously been unable to solve problems.

6. Volunteers on committees that are outside typical job responsibilities; exceeds the expectations of his job in participating in school initiatives and programs.

7. Proactively works with teachers and students to improve collaboration and functioning on a continuous basis.

E. Creativity And Innovation

1. Takes "smart" risks including trying new and different ways to get the job done.

2. Relentlessly challenges the status quo to ensure area for improvement are identified and addressed. 
3. Inspires others to develop and implement new ideas and ways to approach to work that benefit the State and its customers.

4. Champions innovative approaches within the department by acting as an opinion leader whom others emulate.

5. Encourages new ideas, and motivates others to be proactive, resourceful, and know the customer.

6. Creates and implements customized processes and practices that demonstrate "best practices" for the school.

7. Identifies and visualizes options and formulates innovative approaches.

8. Foster an environment that supports the smooth implementation of new approaches/programs.

9. Develops creative and highly effective ways of doing work/services provided by the school.

10. Generates support among co-workers for even the most controversial ideas and concepts.

\section{Part 2 - Teachers Instructional Competence}

Following directions were given to the survey participating teachers:

Directions: Listed below are statements that describe your classroom behavior. Each statement describes a specific kind of behavior. Rate yourself according to the rating key that corresponds to your behavior, ability, and other matters related to your responsibility and accountability as a teacher.

\section{Rating Key:}

$$
\begin{aligned}
& 4=\text { Very good } \\
& 3=\text { Good } \\
& 2=\text { Average } \\
& 1=\text { Below average } \\
& 0=\text { Unsatisfactory }
\end{aligned}
$$

\section{Teachers' Instructional Competence}

\section{Teachers' Planning and Preparation}

1. The teacher prepares lesson plans that are well laid out and sequenced.

2. The teacher writes objectives that are SMART.

3. The teacher writes objectives that are level appropriate.

4. The teachers prepare content that is a good match for the objectives.

5. The teacher plans activities that are well differentiated.

6. The teacher prepares instruction with opportunities for individual work.

7. The teacher prepares instructional materials that are adequate.

8. The teacher include timing as an integral part of planning.

9. The teacher is well organized for lesson presentation.

10. The teacher prepares assessment exercises to monitor students' learning.

\section{Teachers Instructional Process}

1. The teacher makes objectives explicit to students at the start of the lesson.

2. The teacher engages students in activities that are appropriate and meaningful.

3. The teacher engages students in activities that encourage them to think. 
4. The teacher uses a variety of teaching strategies to enhance learning.

5. The teacher arouses and maintains students' interest.

6. The teacher uses appropriate instructional materials in the teaching.

7. The teacher uses appropriate questioning techniques.

8. The teacher ensures that all students participate in instructional activities.

9. The teacher guides students to develop concepts/master skills.

10. The teacher presents instruction in a logical and coherent manner.

\section{Teacher's Assessment}

1. The teacher uses appropriate assessment activities to monitor student performance.

2. The teacher provides corrective feedback during the course of the lesson.

3. The teacher provides timely feedback to students on their performance.

4. The teacher provides timely feedback to parents on students' performance.

5. The teacher takes appropriate action based on results of assessment.

\section{Teacher's Professionalism}

1. The teacher expresses himself clearly and is easily understood.

2. The teacher reports for work regularly.

3. The teacher demonstrates maturity in dealing with students.

4. The teacher seeks opportunities for his professional development.

5. The teacher demonstrates sound judgement in decision making.

6. The teacher contributes to the life of the school including co-curricular activities.

7. The teacher demonstrates leadership skills in the performance of duties.

8. The teacher adhere to the code of ethics.

\section{Teachers Interpersonal Relationship}

1. The teacher encourages student to respect the worth and dignity of others.

2. The teacher offers advice to others principal, colleagues, students and parents.

3. The teacher accepts advice from others principal, colleagues, students and parents.

4. The teacher is cooperative and works well with staff members.

5. The teacher demonstrates sensitivity to opinions, and attitudes and feelings of others.

6. Communicates effectively with students, colleagues, and parents.

7. Maintains a good rapport with students, colleagues, and parent.

\section{Teachers Classroom Management}

1. The teacher demonstrates an awareness of what is happening in the classroom.

2. The teacher deals effectively with students' behavior.

3. The teacher is fair in dealing with students.

4. The teacher manages time effectively.

5. The teacher manages and utilizes learning resources effectively.

6. The teacher manages effectively, classroom related activities, assignments, projects and field trips.

7. The teacher ensures that students observe the rules for classroom activities and students' behavior.

8. The teacher demonstrates effective transition from one activity. 
9. The teacher keeps accurate and relevant student records.

\section{Appendix C}

To ensure the correctness of the Statistical Calculations being made in the study, a case processing summary was indicated for every variable which were as follows.

\section{SUMMARIZE}

/TABLES=Q1 Q2 Q3 Q4 Q5 Q6 Q7 Q8 Q9 Q10 Communication

$/$ FORMAT $=$ VALIDLIST NOCASENUM TOTAL LIMIT $=143$

/TITLE $=$ 'Case Summaries'

$/$ MISSING=VARIABLE

$/$ CELLS $=$ COUNT

Case Processing Summary

\begin{tabular}{|c|c|c|c|c|c|c|}
\hline & \multicolumn{6}{|c|}{ Cases } \\
\hline & \multicolumn{2}{|c|}{ Included } & \multicolumn{2}{|c|}{ Excluded } & \multicolumn{2}{|c|}{ Total } \\
\hline & $\mathbf{N}$ & Percent & $\mathbf{N}$ & Percent & $\mathbf{N}$ & Percent \\
\hline Recognize and understand the perspective of other people. & 143 & $100 \%$ & 0 & $0 \%$ & 143 & $100 \%$ \\
\hline Receive feedback and learn from it. & 143 & $100 \%$ & 0 & $0 \%$ & 143 & $100 \%$ \\
\hline Present information to the audience. & 143 & $100 \%$ & 0 & $0 \%$ & 143 & $100 \%$ \\
\hline Great written and oral skills. & 143 & $100 \%$ & 0 & $0 \%$ & 143 & $100 \%$ \\
\hline $\begin{array}{l}\text { Initiate dialogue and involve people in the communication } \\
\text { process. }\end{array}$ & 143 & $100 \%$ & 0 & $0 \%$ & 143 & $100 \%$ \\
\hline $\begin{array}{l}\text { Ability to bring value to people y presenting them certain } \\
\text { information. }\end{array}$ & 143 & $100 \%$ & 0 & $0 \%$ & 143 & $100 \%$ \\
\hline $\begin{array}{l}\text { Establishment of strong connections with people through } \\
\text { communication. }\end{array}$ & 143 & $100 \%$ & 0 & $0 \%$ & 143 & $100 \%$ \\
\hline $\begin{array}{l}\text { Presents an open and accepting persona that allows the most to } \\
\text { reluctant person to express his/her views. }\end{array}$ & 143 & $100 \%$ & 0 & $0 \%$ & 143 & $100 \%$ \\
\hline $\begin{array}{l}\text { Encourages an open exchange of ideas and different points of } \\
\text { view; tells the truth even when it is unwelcome. }\end{array}$ & 143 & $100 \%$ & 0 & $0 \%$ & 143 & $100 \%$ \\
\hline $\begin{array}{l}\text { Demonstrates a keen ability to recognize when others are having } \\
\text { difficulty understanding his messages and adapts style } \\
\text { appropriately. }\end{array}$ & 143 & $100 \%$ & 0 & $0 \%$ & 143 & $100 \%$ \\
\hline Classroom management. & 143 & $100 \%$ & 0 & $0 \%$ & 143 & $100 \%$ \\
\hline
\end{tabular}

GET FILE='C:IUsers \OneDrive \Desktop\spss result \Table 3.sav'

DATASET NAME DataSet1 WINDOW=FRONT

SUMMARIZE

/TABLES=Q1 Q2 Q3 Q4 Q5 Q6 Q7 Q8 Judgement

/FORMAT $=$ VALIDLIST NOCASENUM TOTAL LIMIT $=143$

/TITLE $=$ 'Case Summaries'

/MISSING=VARIABLE

/CELLS $=$ COUNT 
Case Processing Summary

\begin{tabular}{|c|c|c|c|c|c|c|}
\hline & \multicolumn{6}{|c|}{ Cases } \\
\hline & \multicolumn{2}{|c|}{ Included } & \multicolumn{2}{|c|}{ Excluded } & \multicolumn{2}{|c|}{ Total } \\
\hline & $\mathbf{N}$ & Percent & $\mathbf{N}$ & Percent & $\mathbf{N}$ & Percent \\
\hline $\begin{array}{l}\text { Demonstrate an ability to make effective decisions within limited } \\
\text { time. }\end{array}$ & 143 & $100 \%$ & 0 & $0 \%$ & 143 & $100 \%$ \\
\hline Develops highly creative and effective solutions despite & 143 & $100 \%$ & 0 & $0 \%$ & 143 & $100 \%$ \\
\hline The teacher demonstrates maturity in dealing with students. & 143 & $100 \%$ & 0 & $0 \%$ & 143 & $100 \%$ \\
\hline The teacher seeks opportunities for his professional development. & 143 & $100 \%$ & 0 & $0 \%$ & 143 & $100 \%$ \\
\hline The teacher demonstrates sound judgment in decision-making. & 143 & $100 \%$ & 0 & $0 \%$ & 143 & $100 \%$ \\
\hline $\begin{array}{l}\text { The teacher contributes to the life of the school including co- } \\
\text { curricular activities. }\end{array}$ & 143 & $100 \%$ & 0 & $0 \%$ & 143 & $100 \%$ \\
\hline $\begin{array}{l}\text { The teacher demonstrates leadership skills in the performance of } \\
\text { duties. }\end{array}$ & 143 & $100 \%$ & 0 & $0 \%$ & 143 & $100 \%$ \\
\hline The teachers adhere to the code of ethics. & 143 & $100 \%$ & 0 & $0 \%$ & 143 & $100 \%$ \\
\hline Judgement. & 143 & $100 \%$ & 0 & $0 \%$ & 143 & $100 \%$ \\
\hline
\end{tabular}

GET FILE $=$ 'C $: \backslash$ Users $\backslash$ OneDrive $\backslash$ Desktop $\backslash$ spss result $\backslash$ Table 4.sav'

DATASET NAME DataSet2 WINDOW=FRONT

SUMMARIZE

/TABLES=Q1 Q2 Q3 Q4 Q5 Q6 Q7 Q8 Q9 Q10 Leadership

$/$ FORMAT $=$ VALIDLIST NOCASENUM TOTAL LIMIT $=143$

/TITLE='Case Summaries'

$/ \mathrm{MISSING}=\mathrm{VARIABLE}$

$/ \mathrm{CELLS}=\mathrm{COUNT}$

Case Processing Summary

\begin{tabular}{|c|c|c|c|c|c|c|}
\hline & \multicolumn{6}{|c|}{ Cases } \\
\hline & \multicolumn{2}{|c|}{ Included } & \multicolumn{2}{|c|}{ Excluded } & \multicolumn{2}{|c|}{ Total } \\
\hline & $\mathbf{N}$ & Percent & $\mathbf{N}$ & Percent & $\mathbf{N}$ & Percent \\
\hline $\begin{array}{l}\text { Encourages a sense of mutual accountability in class settings that } \\
\text { motivates students to do his best for each other and exceed goals. }\end{array}$ & 143 & $100 \%$ & 0 & $0 \%$ & 143 & $100 \%$ \\
\hline $\begin{array}{l}\text { Identifies the most important priorities for the class and focuses } \\
\text { attention effectively. }\end{array}$ & 143 & $100 \%$ & 0 & $0 \%$ & 143 & $100 \%$ \\
\hline $\begin{array}{l}\text { Provides direction to less experienced teacher on how to monitor } \\
\text { the class without interfering student progress }\end{array}$ & 143 & $100 \%$ & 0 & $0 \%$ & 143 & $100 \%$ \\
\hline $\begin{array}{l}\text { Demonstrates an ability to identify underlying performance } \\
\text { issues among the class and delivery highly insightful feedback. }\end{array}$ & 143 & $100 \%$ & 0 & $0 \%$ & 143 & $100 \%$ \\
\hline $\begin{array}{l}\text { Effective gives constructive feedback even when the message is } \\
\text { extremely difficult to deliver }\end{array}$ & 143 & $100 \%$ & 0 & $0 \%$ & 143 & $100 \%$ \\
\hline $\begin{array}{l}\text { Helps the students develop their ability to anticipate problems by } \\
\text { leveraging their past experiences so that they can work } \\
\text { independently }\end{array}$ & 143 & $100 \%$ & 0 & $0 \%$ & 143 & $100 \%$ \\
\hline $\begin{array}{l}\text { Positive influence on other teachers and students and their } \\
\text { motivation }\end{array}$ & 143 & $100 \%$ & 0 & $0 \%$ & 143 & $100 \%$ \\
\hline
\end{tabular}




\begin{tabular}{|l|l|l|l|l|l|l|}
\hline Ability to serve as an example and act correspondingly & 143 & $100 \%$ & 0 & $0 \%$ & 143 & $100 \%$ \\
\hline Ability to take responsibility and accountability. & 143 & $100 \%$ & 0 & $0 \%$ & 143 & $100 \%$ \\
\hline Ability to encourage, coach, teach and assist other people & 143 & $100 \%$ & 0 & $0 \%$ & 143 & $100 \%$ \\
\hline Leadership & 143 & $100 \%$ & 0 & $0 \%$ & 143 & $100 \%$ \\
\hline a. Limited to first 143 cases.
\end{tabular}

\section{DATASET ACTIVATE DataSet1}

\section{DATASET CLOSE DataSet2}

GET FILE $=$ 'C: $\backslash$ Users $\backslash$ OneDrive $\backslash$ Desktop $\backslash$ spss result $\backslash$ Table 5.sav'

DATASET NAME DataSet3 WINDOW=FRONT.

\section{SUMMARIZE}

/TABLES=Q1 Q2 Q3 Q4 Q5 Q6 Q7 Teamwork

$/$ FORMAT $=$ VALIDLIST NOCASENUM TOTAL LIMIT=143

/TITLE='Case Summaries'

$/ \mathrm{MISSING}=\mathrm{VARIABLE}$

$/ \mathrm{CELLS}=\mathrm{COUNT}$

\section{Case Processing Summary}

\begin{tabular}{|c|c|c|c|c|c|c|}
\hline & \multicolumn{6}{|c|}{ Cases } \\
\hline & \multicolumn{2}{|c|}{ Included } & \multicolumn{2}{|c|}{ Excluded } & \multicolumn{2}{|c|}{ Total } \\
\hline & $\mathbf{N}$ & Percent & $\mathbf{N}$ & Percent & $\mathbf{N}$ & Percent \\
\hline $\begin{array}{l}\text { Frequently uses opportunities to work with others as a teaching } \\
\text { tool to impart organizational knowledge and help others succeed. }\end{array}$ & 143 & $100 \%$ & 0 & $0 \%$ & 143 & $100 \%$ \\
\hline $\begin{array}{l}\text { Actively seeks to eliminate "cliques" and assists in problem } \\
\text { solving so that all teachers and students can be included in work } \\
\text { processes. }\end{array}$ & 143 & $100 \%$ & 0 & $0 \%$ & 143 & $100 \%$ \\
\hline Builds loyalty among other teachers in the organization. & 143 & $100 \%$ & 0 & $0 \%$ & 143 & $100 \%$ \\
\hline $\begin{array}{l}\text { Provides guidance to others as they work through conflicts and } \\
\text { disagreements so they can become better "team players". }\end{array}$ & 143 & $100 \%$ & 0 & $0 \%$ & 143 & $100 \%$ \\
\hline $\begin{array}{l}\text { Facilitates communication between people experiencing conflict } \\
\text { who have previously been unable to solve problems }\end{array}$ & 143 & $100 \%$ & 0 & $0 \%$ & 143 & $100 \%$ \\
\hline $\begin{array}{l}\text { Volunteers on committees that are outside typical job } \\
\text { responsibilities; exceeds the expectations of his job in } \\
\text { participating in school initiatives and programs. }\end{array}$ & 143 & $100 \%$ & 0 & $0 \%$ & 143 & $100 \%$ \\
\hline $\begin{array}{l}\text { Proactively works with teachers and students to improve } \\
\text { collaboration and functioning on a continuous basis. }\end{array}$ & 143 & $100 \%$ & 0 & $0 \%$ & 143 & $100 \%$ \\
\hline Teamwork. & 143 & $100 \%$ & 0 & $0 \%$ & 143 & $100 \%$ \\
\hline
\end{tabular}

DATASET ACTIVATE DataSet1

DATASET CLOSE DataSet3

GET FILE='C: $\backslash$ Users $\backslash$ OneDrive $\backslash$ Desktop $\backslash$ spss result $\backslash$ Table 6.sav'

DATASET NAME DataSet4 WINDOW=FRONT

\section{SUMMARIZE}

/TABLES=Q1 Q2 Q3 Q4 Q5 Q6 Q7 Q8 Q9 Q10 Creativity

/FORMAT=VALIDLIST NOCASENUM TOTAL LIMIT=143

/TITLE $=$ 'Case Summaries'

$/ \mathrm{MISSING}=$ VARIABLE 


\section{/CELLS=COUNT}

Case Processing Summary

\begin{tabular}{|l|c|c|c|c|c|c|}
\hline \multirow{2}{*}{} & \multicolumn{4}{|c|}{ Cases } \\
\cline { 2 - 7 } & \multicolumn{2}{|c|}{ Included } & \multicolumn{2}{|c|}{ Excluded } & \multicolumn{2}{|c|}{ Total } \\
\cline { 2 - 7 } & $\mathbf{N}$ & Percent & N & Percent & N & Percent \\
\hline $\begin{array}{l}\text { Takes "smart" risks including trying new and different ways to } \\
\text { get the job done. }\end{array}$ & 143 & $100 \%$ & 0 & $0 \%$ & 143 & $100 \%$ \\
\hline $\begin{array}{l}\text { Relentlessly challenges the status quo to ensure area for } \\
\text { improvement are identified and addressed. }\end{array}$ & 143 & $100 \%$ & 0 & $0 \%$ & 143 & $100 \%$ \\
\hline $\begin{array}{l}\text { Inspires others to develop and implement new ideas and ways to } \\
\text { approach to work hat benefit the State and its customers. }\end{array}$ & 143 & $100 \%$ & 0 & $0 \%$ & 143 & $100 \%$ \\
\hline $\begin{array}{l}\text { Champions innovative approaches within the department by } \\
\text { acting as an opinion leader whom others emulate. }\end{array}$ & 143 & $100 \%$ & 0 & $0 \%$ & 143 & $100 \%$ \\
\hline $\begin{array}{l}\text { Encourages new ideas, and motivates others to be proactive, } \\
\text { resourceful, and know the customer. }\end{array}$ & 143 & $100 \%$ & 0 & $0 \%$ & 143 & $100 \%$ \\
\hline $\begin{array}{l}\text { Creates and implements customized processes and practices that } \\
\text { demonstrate "best practices" for the school. }\end{array}$ & 143 & $100 \%$ & 0 & $0 \%$ & 143 & $100 \%$ \\
\hline $\begin{array}{l}\text { Identifies and visualizes options and formulates innovative } \\
\text { approaches. }\end{array}$ & 143 & $100 \%$ & 0 & $0 \%$ & 143 & $100 \%$ \\
\hline $\begin{array}{l}\text { Foster an environment that supports the smooth implementation } \\
\text { of new approaches/programs. }\end{array}$ & 143 & $100 \%$ & 0 & $0 \%$ & 143 & $100 \%$ \\
\hline $\begin{array}{l}\text { Develops creative and highly effective ways of doing } \\
\text { work/services provided by the school. }\end{array}$ & 143 & $100 \%$ & 0 & $0 \%$ & 143 & $100 \%$ \\
\hline $\begin{array}{l}\text { Generates support among co-workers for even the most } \\
\text { controversial ideas and concepts. }\end{array}$ & 143 & $100 \%$ & 0 & $0 \%$ & 143 & $100 \%$ \\
\hline Creativity. & 143 & $100 \%$ & 0 & $0 \%$ & 143 & $100 \%$ \\
\hline a. Limited to first 143 cases. & & & & \\
\hline
\end{tabular}

\section{DATASET ACTIVATE DataSet1}

DATASET CLOSE DataSet4

GET FILE $=$ 'C:|Users\OneDrive $\backslash$ Desktop \spss result|Table 7.sav'

DATASET NAME DataSet5 WINDOW=FRONT

SUMMARIZE

/TABLES=Q1 Q2 Q3 Q4 Q5 Q6 Q7 Q8 Q9 Q10 Planning

$/$ FORMAT $=$ VALIDLIST NOCASENUM TOTAL LIMIT $=143$

/TITLE='Case Summaries'

/MISSING=VARIABLE

$/$ CELLS $=$ COUNT

Case Processing Summary

\begin{tabular}{|l|c|c|c|c|c|c|}
\hline \multirow{2}{*}{} & \multicolumn{5}{|c|}{ Cases } \\
\cline { 2 - 7 } & \multicolumn{2}{|c|}{ Included } & \multicolumn{2}{|c|}{ Excluded } & \multicolumn{2}{|c|}{ Total } \\
\cline { 2 - 7 } & $\mathbf{N}$ & Percent & N & Percent & N & Percent \\
\hline $\begin{array}{l}\text { The teacher prepares lesson plans that are well laid out and } \\
\text { sequenced. }\end{array}$ & 143 & $100 \%$ & 0 & $0 \%$ & 143 & $100 \%$ \\
\hline The teacher writes objectives that are SMART. & 143 & $100 \%$ & 0 & $0 \%$ & 143 & $100 \%$ \\
\hline
\end{tabular}




\begin{tabular}{|c|c|c|c|c|c|c|}
\hline The teacher writes objectives that are level appropriate. & 143 & $100 \%$ & 0 & $0 \%$ & 143 & $100 \%$ \\
\hline $\begin{array}{l}\text { The teachers prepare content that is a good match for the } \\
\text { objectives. }\end{array}$ & 143 & $100 \%$ & 0 & $0 \%$ & 143 & $100 \%$ \\
\hline The teacher plans activities that are well differentiated. & 143 & $100 \%$ & 0 & $0 \%$ & 143 & $100 \%$ \\
\hline $\begin{array}{l}\text { The teacher prepares instruction with opportunities for individual } \\
\text { work. }\end{array}$ & 143 & $100 \%$ & 0 & $0 \%$ & 143 & $100 \%$ \\
\hline The teacher prepares instructional materials that are adequate. & 143 & $100 \%$ & 0 & $0 \%$ & 143 & $100 \%$ \\
\hline The teacher include timing as an integral part of planning. & 143 & $100 \%$ & 0 & $0 \%$ & 143 & $100 \%$ \\
\hline The teacher is well organized for lesson presentation. & 143 & $100 \%$ & 0 & $0 \%$ & 143 & $100 \%$ \\
\hline $\begin{array}{l}\text { The teacher prepares assessment exercises to monitor students' } \\
\text { learning. }\end{array}$ & 143 & $100 \%$ & 0 & $0 \%$ & 143 & $100 \%$ \\
\hline Planning. & 143 & $100 \%$ & 0 & $0 \%$ & 143 & $100 \%$ \\
\hline
\end{tabular}

DATASET ACTIVATE DataSet1

DATASET CLOSE DataSet5

GET FILE='C: $\backslash$ Users $\backslash$ OneDrive $\backslash$ Desktop $\backslash$ spss result $\backslash$ Table 8.sav'

DATASET NAME DataSet6 WINDOW=FRONT

SUMMARIZE

/TABLES=Q1 Q2 Q3 Q4 Q5 Q6 Q7 Q8 Q9 Q10 InstructionalProcess

$/$ FORMAT $=$ VALIDLIST NOCASENUM TOTAL LIMIT $=143$

/TITLE $=$ 'Case Summaries'

$/ \mathrm{MISSING}=\mathrm{VARIABLE}$

$/ \mathrm{CELLS}=\mathrm{COUNT}$

\section{Case Processing Summary}

\begin{tabular}{|c|c|c|c|c|c|c|}
\hline & \multicolumn{6}{|c|}{ Cases } \\
\hline & \multicolumn{2}{|c|}{ Included } & \multicolumn{2}{|c|}{ Excluded } & \multicolumn{2}{|c|}{ Total } \\
\hline & $\mathbf{N}$ & Percent & $\mathbf{N}$ & Percent & $\mathbf{N}$ & Percent \\
\hline $\begin{array}{l}\text { The teacher makes objectives explicit to students at the start of } \\
\text { the lesson. }\end{array}$ & 143 & $100 \%$ & 0 & $0 \%$ & 143 & $100 \%$ \\
\hline $\begin{array}{l}\text { The teacher engages students in activities that are appropriate and } \\
\text { meaningful. }\end{array}$ & 143 & $100 \%$ & 0 & $0 \%$ & 143 & $100 \%$ \\
\hline $\begin{array}{l}\text { The teacher engages students in activities that encourage them to } \\
\text { think. }\end{array}$ & 143 & $100 \%$ & 0 & $0 \%$ & 143 & $100 \%$ \\
\hline $\begin{array}{l}\text { The teacher uses a variety of teaching strategies to enhance } \\
\text { learning. }\end{array}$ & 143 & $100 \%$ & 0 & $0 \%$ & 143 & $100 \%$ \\
\hline The teacher arouses and maintains students' interest. & 143 & $100 \%$ & 0 & $0 \%$ & 143 & $100 \%$ \\
\hline $\begin{array}{l}\text { The teacher uses appropriate instructional materials in the } \\
\text { teaching. }\end{array}$ & 143 & $100 \%$ & 0 & $0 \%$ & 143 & $100 \%$ \\
\hline The teacher uses appropriate questioning techniques. & 143 & $100 \%$ & 0 & $0 \%$ & 143 & $100 \%$ \\
\hline $\begin{array}{l}\text { The teacher ensures that all students participate in instructional } \\
\text { activities. }\end{array}$ & 143 & $100 \%$ & 0 & $0 \%$ & 143 & $100 \%$ \\
\hline The teacher guides students to develop concepts/master skills. & 143 & $100 \%$ & 0 & $0 \%$ & 143 & $100 \%$ \\
\hline The teacher presents instruction in a logical and coherent manner. & 143 & $100 \%$ & 0 & $0 \%$ & 143 & $100 \%$ \\
\hline Instructional Process. & 143 & $100 \%$ & 0 & $0 \%$ & 143 & $100 \%$ \\
\hline
\end{tabular}


a. Limited to first 143 cases.

\section{DATASET ACTIVATE DataSet1}

DATASET CLOSE DataSet6

GET FILE $=$ 'C: $\backslash$ Users $\backslash$ OneDrive $\backslash$ Desktop $\backslash$ spss result $\backslash$ tABLE 9.sav'

DATASET NAME DataSet7 WINDOW=FRONT

SUMMARIZE

/TABLES=Q1 Q2 Q3 Q4 Q5 Assessment

$/$ FORMAT $=$ VALIDLIST NOCASENUM TOTAL LIMIT $=143$

/TITLE $=$ 'Case Summaries'

$/$ MISSING=VARIABLE

$/ \mathrm{CELLS}=\mathrm{COUNT}$

Case Processing Summary

\begin{tabular}{|c|c|c|c|c|c|c|}
\hline & \multicolumn{6}{|c|}{ Cases } \\
\hline & \multicolumn{2}{|c|}{ Included } & \multicolumn{2}{|c|}{ Excluded } & \multicolumn{2}{|c|}{ Total } \\
\hline & $\mathrm{N}$ & Percent & $\mathrm{N}$ & Percent & $\mathbf{N}$ & Percent \\
\hline $\begin{array}{l}\text { The teacher uses appropriate assessment activities to monitor } \\
\text { student performance. }\end{array}$ & 143 & $100 \%$ & 0 & $0 \%$ & 143 & $100 \%$ \\
\hline $\begin{array}{l}\text { The teacher provides corrective feedback during the course of the } \\
\text { lesson. }\end{array}$ & 143 & $100 \%$ & 0 & $0 \%$ & 143 & $100 \%$ \\
\hline $\begin{array}{l}\text { The teacher provides timely feedback to students on their } \\
\text { performance. }\end{array}$ & 143 & $100 \%$ & 0 & $0 \%$ & 143 & $100 \%$ \\
\hline $\begin{array}{l}\text { The teacher provides timely feedback to parents on students } \\
\text { performance. }\end{array}$ & 143 & $100 \%$ & 0 & $0 \%$ & 143 & $100 \%$ \\
\hline $\begin{array}{l}\text { The teacher takes appropriate action based on results of } \\
\text { assessment. }\end{array}$ & 143 & $100 \%$ & 0 & $0 \%$ & 143 & $100 \%$ \\
\hline Assessment. & 143 & $100 \%$ & 0 & $0 \%$ & 143 & $100 \%$ \\
\hline
\end{tabular}

\section{DATASET ACTIVATE DataSet1}

DATASET CLOSE DataSet7

GET FILE $=$ 'C : $\backslash$ Users $\backslash$ OneDrive $\backslash$ Desktop $\backslash$ spss result $\backslash$ TABLE 10.sav'

DATASET NAME DataSet8 WINDOW=FRONT

SUMMARIZE

/TABLES=Q1 Q2 Q3 Q4 Q5 Q6 Q7 Q8 Professionalism

$/$ FORMAT $=$ VALIDLIST NOCASENUM TOTAL LIMIT $=143$

/TITLE $=$ 'Case Summaries'

/MISSING=VARIABLE

$/ \mathrm{CELLS}=\mathrm{COUNT}$

Case Processing Summary

\begin{tabular}{|l|c|c|c|c|c|c|}
\hline \multirow{2}{*}{} & \multicolumn{5}{|c|}{ Cases } \\
\cline { 2 - 7 } & \multicolumn{2}{|c|}{ Included } & \multicolumn{3}{|c|}{ Excluded } & \multicolumn{2}{|c|}{ Total } \\
\cline { 2 - 7 } & $\mathrm{N}$ & Percent & $\mathrm{N}$ & Percent & N & Percent \\
\hline The teacher expresses himself clearly and is easily understood. & 143 & $100 \%$ & 0 & $0 \%$ & 143 & $100 \%$ \\
\hline The teacher reports for work regularly. & 143 & $100 \%$ & 0 & $0 \%$ & 143 & $100 \%$ \\
\hline
\end{tabular}




\begin{tabular}{|l|l|l|l|l|l|l|}
\hline The teacher demonstrates maturity in dealing with students. & 143 & $100 \%$ & 0 & $0 \%$ & 143 & $100 \%$ \\
\hline The teacher seeks opportunities for his professional development. & 143 & $100 \%$ & 0 & $0 \%$ & 143 & $100 \%$ \\
\hline The teacher demonstrates sound judgement in decision making. & 143 & $100 \%$ & 0 & $0 \%$ & 143 & $100 \%$ \\
\hline $\begin{array}{l}\text { The teacher contributes to the life of the school including co- } \\
\text { curricular activities. }\end{array}$ & 143 & $100 \%$ & 0 & $0 \%$ & 143 & $100 \%$ \\
\hline $\begin{array}{l}\text { The teacher demonstrates leadership skills in the performance of } \\
\text { duties. }\end{array}$ & 143 & $100 \%$ & 0 & $0 \%$ & 143 & $100 \%$ \\
\hline The teacher adhere to the code of ethics. & 143 & $100 \%$ & 0 & $0 \%$ & 143 & $100 \%$ \\
\hline Professionalism & 143 & $100 \%$ & 0 & $0 \%$ & 143 & $100 \%$ \\
\hline a. Limited to first 143 cases. & & \\
\hline
\end{tabular}

GET FILE $=$ 'C: $\backslash$ Users $\backslash$ OneDrive $\backslash$ Desktop $\backslash$ spss result $\backslash$ Table 11.sav'

DATASET NAME DataSet9 WINDOW=FRONT

\section{SUMMARIZE}

/TABLES=Q1 Q2 Q3 Q4 Q5 Q6 Q7 International

$/$ FORMAT $=$ VALIDLIST NOCASENUM TOTAL LIMIT=143

/TITLE='Case Summaries'

$/ \mathrm{MISSING}=\mathrm{VARIABLE}$

$/ \mathrm{CELLS}=\mathrm{COUNT}$

Case Processing Summary

\begin{tabular}{|c|c|c|c|c|c|c|}
\hline & \multicolumn{6}{|c|}{ Cases } \\
\hline & \multicolumn{2}{|c|}{ Included } & \multicolumn{2}{|c|}{ Excluded } & \multicolumn{2}{|c|}{ Total } \\
\hline & $\mathbf{N}$ & Percent & $\mathbf{N}$ & Percent & $\mathbf{N}$ & Percent \\
\hline $\begin{array}{l}\text { The teacher encourages students to respect the worth and dignity } \\
\text { of others. }\end{array}$ & 143 & $100 \%$ & 0 & $0 \%$ & 143 & $100 \%$ \\
\hline $\begin{array}{l}\text { The teacher offers advice to the others - principal, colleagues, } \\
\text { students and parents. }\end{array}$ & 143 & $100 \%$ & 0 & $0 \%$ & 143 & $100 \%$ \\
\hline $\begin{array}{l}\text { The teacher accepts advice from others - principal, colleagues, } \\
\text { students and parents. }\end{array}$ & 143 & $100 \%$ & 0 & $0 \%$ & 143 & $100 \%$ \\
\hline The teacher is cooperative and works well with staff members. & 143 & $100 \%$ & 0 & $0 \%$ & 143 & $100 \%$ \\
\hline $\begin{array}{l}\text { The teacher demonstrates sensitivity to opinions and attitudes and } \\
\text { feelings of others. }\end{array}$ & 143 & $100 \%$ & 0 & $0 \%$ & 143 & $100 \%$ \\
\hline Communicates effectively with students, colleagues and parents. & 143 & $100 \%$ & 0 & $0 \%$ & 143 & $100 \%$ \\
\hline Maintains a good rapport with students, colleagues and parents. & 143 & $100 \%$ & 0 & $0 \%$ & 143 & $100 \%$ \\
\hline
\end{tabular}

DATASET ACTIVATE DataSet1

DATASET CLOSE DataSet9

GET FILE='C: $\backslash$ Users $\backslash$ OneDrive $\backslash$ Desktop $\backslash$ spss result $\backslash$ Table 12.sav'

DATASET NAME DataSet10 WINDOW=FRONT

SUMMARIZE

/TABLES=Q1 Q2 Q3 Q4 Q5 Q6 Q7 Q8 Q9 Classroom Management

$/$ FORMAT $=$ VALIDLIST NOCASENUM TOTAL LIMIT $=143$

/TITLE='Case Summaries'

$/ \mathrm{MISSING}=\mathrm{VARIABLE}$

$/ \mathrm{CELLS}=\mathrm{COUNT}$ 
Case Processing Summary

\begin{tabular}{|c|c|c|c|c|c|c|}
\hline & \multicolumn{6}{|c|}{ Cases } \\
\hline & \multicolumn{2}{|c|}{ Included } & \multicolumn{2}{|c|}{ Excluded } & \multicolumn{2}{|c|}{ Total } \\
\hline & $\mathbf{N}$ & Percent & $\mathrm{N}$ & Percent & $\mathbf{N}$ & Percent \\
\hline $\begin{array}{l}\text { The teacher demonstrates an awareness of what is happening in } \\
\text { the classroom. }\end{array}$ & 143 & $100 \%$ & 0 & $0 \%$ & 143 & $100 \%$ \\
\hline The teacher deals effectively with students' behavior. & 143 & $100 \%$ & 0 & $0 \%$ & 143 & $100 \%$ \\
\hline The teacher is fair in dealing with students. & 143 & $100 \%$ & 0 & $0 \%$ & 143 & $100 \%$ \\
\hline The teacher manages time effectively. & 143 & $100 \%$ & 0 & $0 \%$ & 143 & $100 \%$ \\
\hline The teacher manages and utilizes learning resources effectively. & 143 & $100 \%$ & 0 & $0 \%$ & 143 & $100 \%$ \\
\hline $\begin{array}{l}\text { The teacher manages effectively, classroom-related activities, } \\
\text { assignments, projects and field trips. }\end{array}$ & 143 & $100 \%$ & 0 & $0 \%$ & 143 & $100 \%$ \\
\hline $\begin{array}{l}\text { The teacher ensures that students observe the rules for classroom } \\
\text { activities and students' behavior. }\end{array}$ & 143 & $100 \%$ & 0 & $0 \%$ & 143 & $100 \%$ \\
\hline The teacher demonstrates effective transition from one activity. & 143 & $100 \%$ & 0 & $0 \%$ & 143 & $100 \%$ \\
\hline The teacher keeps accurate and relevant student records. & 143 & $100 \%$ & 0 & $0 \%$ & 143 & $100 \%$ \\
\hline Classroom Management. & 143 & $100 \%$ & 0 & $0 \%$ & 143 & $100 \%$ \\
\hline
\end{tabular}

GET FILE='C: $\backslash$ Users $\backslash$ OneDrive $\backslash$ Desktop $\backslash$ spss result $\backslash$ Chi-Square.sav'

DATASET NAME DataSet11 WINDOW=FRONT

SUMMARIZE

/TABLES=Communication Judgement Leadership Teamwork Creativity Planning Instructional Process

Assessment Professionalism International Classroom

$/$ FORMAT $=$ VALIDLIST NOCASENUM TOTAL LIMIT=143

/TITLE $=$ 'Case Summaries'

$/$ MISSING=VARIABLE

$/ \mathrm{CELLS}=\mathrm{COUNT}$

Case Processing Summary

\begin{tabular}{|l|c|c|c|c|c|c|}
\hline \multirow{2}{*}{} & \multicolumn{5}{|c|}{ Cases } \\
\cline { 2 - 7 } & \multicolumn{2}{|c|}{ Included } & \multicolumn{2}{c|}{ Excluded } & \multicolumn{2}{c|}{ Total } \\
\cline { 2 - 7 } & $\mathbf{N}$ & Percent & N & Percent & N & Percent \\
\hline Communication & 143 & $100 \%$ & 0 & $0 \%$ & 143 & $100 \%$ \\
\hline Judgement & 143 & $100 \%$ & 0 & $0 \%$ & 143 & $100 \%$ \\
\hline Leadership & 143 & $100 \%$ & 0 & $0 \%$ & 143 & $100 \%$ \\
\hline Teamwork & 143 & $100 \%$ & 0 & $0 \%$ & 143 & $100 \%$ \\
\hline Creativity & 143 & $100 \%$ & 0 & $0 \%$ & 143 & $100 \%$ \\
\hline Planning & 143 & $100 \%$ & 0 & $0 \%$ & 143 & $100 \%$ \\
\hline Instructional Process & 143 & $100 \%$ & 0 & $0 \%$ & 143 & $100 \%$ \\
\hline Assessment & 143 & $100 \%$ & 0 & $0 \%$ & 143 & $100 \%$ \\
\hline Professionalism & 143 & $100 \%$ & 0 & $0 \%$ & 143 & $100 \%$ \\
\hline International & 143 & $100 \%$ & 0 & $0 \%$ & 143 & $100 \%$ \\
\hline Classroom & 143 & $100 \%$ & 0 & $0 \%$ & 143 & $100 \%$ \\
\hline a. Limited to first 143 cases. & & & & & \\
\hline
\end{tabular}

